\title{
Geological and Palaeontological context of three new Barremian (Lower Cretaceous) vertebrate sites in the Iberian Peninsula (Cuenca Province, Central Spain)
}

\author{
F. Barroso-Barcenilla ${ }^{\mathrm{a}, \mathrm{b}, *}$, M. Berrocal-Casero ${ }^{\mathrm{b}}$, H.A. Blain $^{\mathrm{c}}$, P.M. Callapez ${ }^{\mathrm{d}}$, \\ O. Cambra-Moo ${ }^{\mathrm{e}}$, F. Escaso ${ }^{\mathrm{f}}$, C. Martín-Closas ${ }^{\mathrm{g}}$, F. Ortega ${ }^{\mathrm{f}}$, A. Pérez-García ${ }^{\mathrm{f}}$, I. Prieto ${ }^{\mathrm{b}}$,

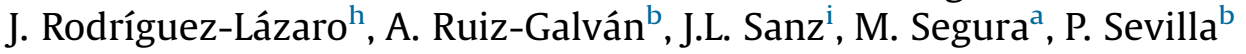 \\ a Departamento de Geología y Geografía (Grupo de Investigación IberCreta), Universidad de Alcalá, 28871 Alcalá de Henares, Spain \\ b Departamento de Paleontología (Grupo de Investigación Procesos Bióticos Mesozoicos), Universidad Complutense de Madrid, 28040 Madrid, Spain \\ c Àrea de Prehistòria and Institut Català de Paleoecologia Humana i Evolució Social (IPHES), Universitat Rovira $i$ Virgili, 43003 Tarragona, Spain \\ d Departamento de Ciências da Terra (Centro de Investigação da Terra e do Espaço), Universidade de Coimbra, 3000-134 Coimbra, Portugal \\ e Departamento de Biología (Laboratorio de Poblaciones del Pasado), Universidad Autónoma de Madrid, 28049 Madrid, Spain \\ ${ }^{\mathrm{f}}$ Departamento de Física Matemática y de Fluidos (Grupo de Investigación Biología Evolutiva), Universidad Nacional de Educación a Distancia, 28040 Madrid, \\ Spain \\ g Departament d'Dinàmica de la Terra i l'Oceà, Universitat de Barcelona, 08028 Barcelona, Spain

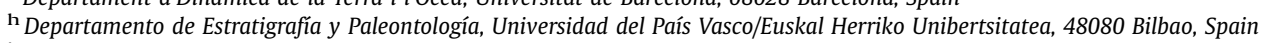 \\ i Departamento de Biología (Grupo de Investigación Biología Evolutiva), Universidad Autónoma de Madrid, 28049 Madrid, Spain
}

\section{A R T I C L E I N F O}

\section{Article history:}

Received 13 June 2016

Received in revised form 22 December 2016

Accepted 24 January 2017

Available online 7 March 2017

\section{Keywords:}

Palaeontological site

Charophytes

Ostracods

Molluscs

Vertebrates

Palaeoenvironment

Upper Barremian

Central Spain

\begin{abstract}
A B S T R A C T
Three new Lower Cretaceous vertebrate sites (Vadillos-1, Vadillos-2, El Tobar) have been recently discovered and studied in the Cuenca Province (Central Spain). They are located in deposits of "Wealden" facies belonging to the El Collado Sandstone and Clay Formation. In these outcrops, micro and macroremains corresponding to plants, invertebrates and vertebrates have been collected and subsequently assigned to macrophytes, charophytes (e.g., Atopochara trivolvis triquetra, Globator maillardii trochiliscoides, Clavator harrisii harrisii), ostracods (e.g., Cypridea gr. modesta, Cypridea cf. C. isasae, Cypridea sp. aff. C. moneta, Cypridea sp. 1, Cypridea sp. 2), molluscs (Unionoida, Viviparus sp.), fishes, amphibians, turtles (cf. Eucryptodira), crocodyliforms (Neosuchia) and dinosaurs (ankylosaurs, ornithopods, theropods). Among the vertebrate remains, scales, teeth, plates, osteoderms, phalanges, ribs, vertebrae and other incomplete bones, as well as eggshell fragments have been identified. This rich and diverse assemblage was deposited in an upper Barremian alluvial-palustrine muddy floodplain crossed by braided sandy channels.
\end{abstract}

(c) 2017 The Geologists' Association. Published by Elsevier Ltd. All rights reserved.

\section{Introduction}

The last few decades have seen an incredible increase in palaeontological studies on the Iberian Peninsula across a wide range of geological ages. These studies have resulted in the discovery of many new fossiliferous localities, especially of Cretaceous vertebrates. A good example of this is the recent discovery of the "Lo Hueco" site during the construction of the Madrid-Levante highspeed railway in Cuenca Province (Barroso-Barcenilla et al., 2009) that, added to the classic site of "Las Hoyas" (Prieto and DíazRomeral, 1989; Buscalioni and Fregenal-Martínez, 2010), shows a

\footnotetext{
* Corresponding author.

E-mail address: fbarroso@geo.ucm.es (F. Barroso-Barcenilla).
}

rich and diverse Cretaceous biota. Preliminary palaeontological evidences from the Beteta Gorges (Lapparent et al., 1969; RuizOmeñaca and Canudo, 2003) allowed the prediction of new vertebrate sites in the North of Cuenca, as happened when vertebrate remains were reported by students (Prieto et al., 2013a, 2013b, 2014; Ruiz-Galván et al., 2013a, 2013b, 2014) of the Universidad Complutense de Madrid (Fig. 1.1-2). As a result, three new sites rich in Lower Cretaceous vertebrate remains were discovered in the Beteta Gorges. A programme of thorough field-work was undertaken in December 2013 and January 2014, being the first integrated conclusions on the integrated analysis of the geological context and the rich palaeontological content (that includes plants, invertebrates, fishes, amphibians, turtles, crocodyliforms and dinosaurs) presented here. 

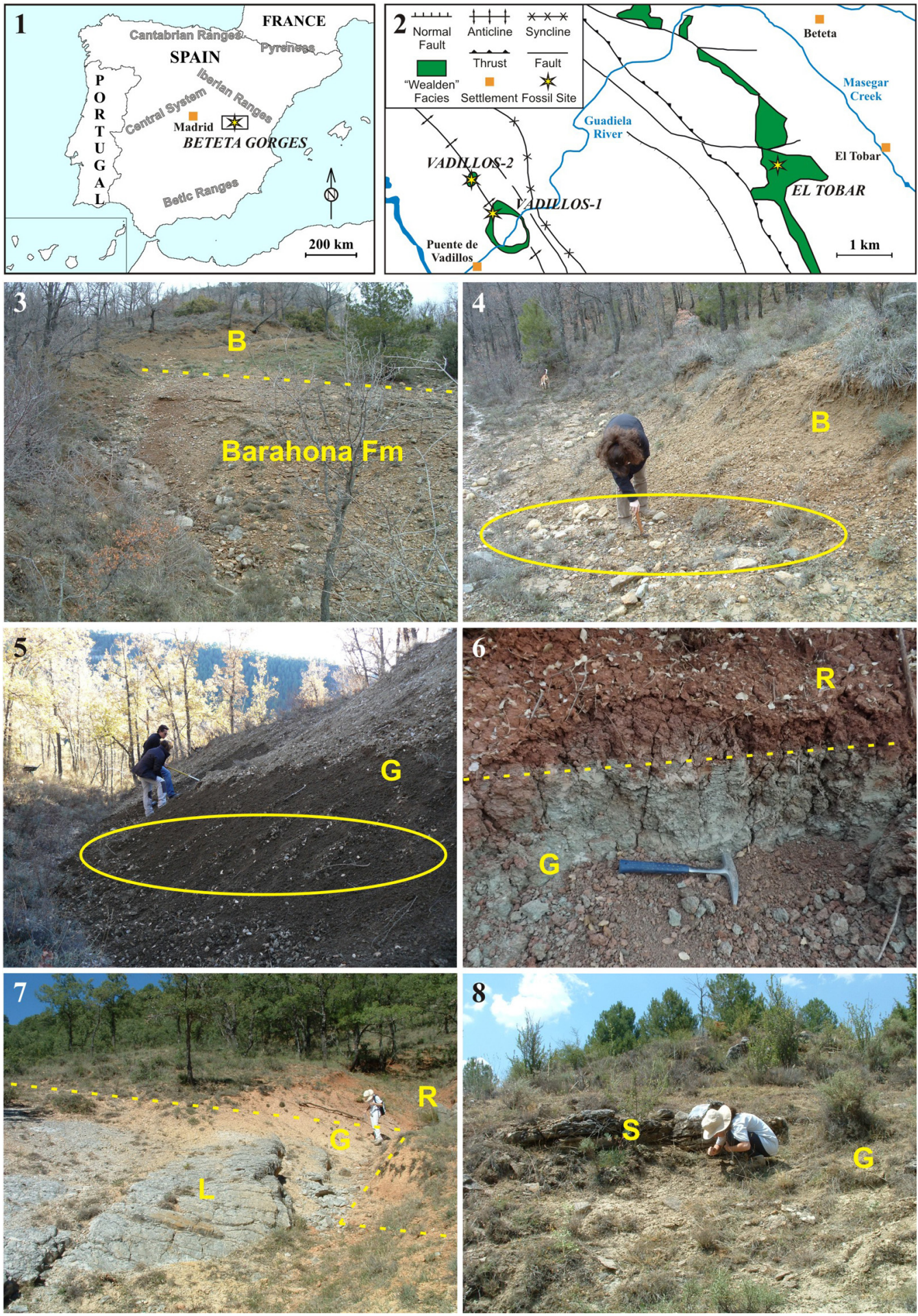

Fig. 1. General geographic (1) and detailed geologic (2) location of the new fossil sites in the Beteta Gorges (Spain). Photographic views of fossiliferous intervals in the Vadillos-1 (3-6), Vadillos-2 (7) and El Tobar (8) sites. 3: Vadillos-1, stratigraphic boundary (dashed yellow line) between the Lower Jurassic Barahona Formation and the lower part of the brown mudstones level (B) of the upper Barremian El Collado Formation; 4: Vadillos-1, concentration of ex-situ calcareous nodules (yellow oval) from the upper part of the brown mudstones level (B); 5: Vadillos-1, concentration of vegetal carbonified remains (yellow circle) in the middle part of the grey mudstones level (G) of the El Collado Formation; 6: Vadillos-1, stratigraphic boundary (dashed yellow line) between the grey (G) and red (R) mudstones levels of the El Collado Formation; 7: Vadillos-2, the sandy limestones (L) in the upper part of grey mudstones level (G) of the El Collado Formation, and stratigraphic boundary (dashed yellow line) between this and the red mudstones level (R); 8: El Tobar, the channels built up of sandy banks (S) in the upper part of grey mudstones level (G) of the El Collado Formation.

\section{Geographical setting}

The new Lower Cretaceous vertebrate sites are located in the Beteta Municipality, in the North of Cuenca Province, Central-eastern
Spain. They lie within the Beteta Gorges, a group of natural canyons cut by the Guadiela River and its tributary, Masegar Creek. This area was studied in detail by Álvaro López and Olmo Zamora (1989a), and is included in the Peralejos de las Truchas Geological Map(Sheet539) 
of Spain. The sites lie in the North of the Serranía de Cuenca Mountains, a part of the Southwestern region of the Castilian Branch of the Iberian Ranges (Fig. 1.1-2).

The first of the three sites to be discovered, Vadillos-1 (European Datum 1950: Lat. $40^{\circ} 32^{\prime}$ 20.27", Long. 2॰ $8^{\prime} 31.21^{\prime \prime}$; UTM 30 X 572663, Y $4488011 \mathrm{~N}$ ) is located close to the Village of Puente de Vadillos, and is part of a Jurassic anticline with wide exposures of overlying Lower Cretaceous mudstones with vertebrate remains. The second site, Vadillos-2 (European Datum 1950: Lat. $40^{\circ} 33^{\prime} 5.54^{\prime \prime}$, Long. $2^{\circ} 8^{\prime}$ 51.37"; UTM 30 X 572178, Y 4489092 $\mathrm{N}$ ) is located to the Northwest of Vadillos-1, in a small valley with fossiliferous Lower Cretaceous mudstones and limestones. The third site, El Tobar (European Datum 1950: Lat. 40 33' 5.54", Long. $2^{\circ} 4^{\prime} 52.97 "$ W; UTM 30 X 577783, Y $4489459 \mathrm{~N}$ ) is located to the East of Vadillos-1, close to the El Tobar Village, on a slope with fossiliferous Lower Cretaceous sandy mudstones (Fig. 1.1-8).

\section{Historical background}

The existence of vertebrate remains in Vadillos (without precise geographical location) was first observed by Curnelle (1968). This author, in his study on the Geology of the Serranía de Cuenca Mountains, cited sauropod, theropod and Iguanodon bones in this outcrop. Lapparent et al. (1969) analysed in detail the palaeontological material collected by Curnelle and assigned the site to the Hauterivian-Barremian on the basis of charophytes, such as Flabellochara sp. and Atopochara trivolvis triquetra. The vertebrate fossils were attributed to Sauropoda indet. (remains include six caudal vertebrae and some fragments of long bones), Theropoda indet. (two dorsal vertebrae, one caudal vertebra and a tibia) and Iguanodon sp. (mainly four vertebrae that currently just can be attributed to a basal Styracosterna: Lapparent et al., 1969). Nonetheless, these authors (Curnelle, 1968; Lapparent et al., 1969) indicated that the remains were collected from undetermined levels of red clays and coarse gravels, unlike the fossil vertebrates here described, that mostly derive from grey mudstones.

Part of this historical fossil material from Vadillos was subsequently lost while another part was taken to the Muséum National d'Histoire Naturelle de Paris (France), where it was revised by Ruiz-Omeñaca and Canudo (2003), assigning the sauropod vertebrae to Titanosauriformes indet. These authors reconsidered the age of the site, dating it with more precision as upper Barremian on the basis of charophyte biostratigraphy. This age was confirmed by Vicente and Martín-Closas (2013), who highlighted the biostratigraphic importance of the charophytes identified in the La Huérguina Formation, which belong to the Ascidiella cruciata-Pseudoglobator paucibracteatus biozone. This charophyte assemblage was previously correlated by MartínClosas et al. (2009) with foraminifera and ammonites, ranging from the Vandenheckii (upper Barremian) to the Weisii (basal Lower Aptian) zones in the Subalpine Chains.

Close to the newly discovered El Tobar site is the Masegosa outcrop, where Sanz (1985) collected and described an ornithopod caudal vertebra, attributing it to Iguanodon bernissartensis on the basis of its large size. Ruiz-Omeñaca et al. (1998) were cautious with the taxonomic determination of this material as the main part of the styracosternan bones recovered in Spain were classified as $I$. bernissartiensis or I. atherfieldensis, sometimes on the basis of limited diagnostic features, such as size. On this basis, new material from Vadillos-1, Vadillos-2 and El Tobar, preliminary described by Prieto et al. (2013a, 2013b, 2014) and Ruiz-Galván et al. (2013a, 2013b, 2014), could help to clarify the identification of these and other dinosaur remains, perhaps adding new taxa (e.g., Thyreophora?) to the Lower Cretaceous record of the Serranía de Cuenca Mountains. Moreover, the present study adds notably to the fossil diversity and abundance previously described from Vadillos by Lapparent et al. (1969).

\section{Stratigraphy and sedimentology}

Geologically, the three new outcrops belong to clastic lithologies with grey and red mudstones in "Wealden" facies (sensu López Olmedo and Gállego Coiduras, 1976). These facies were first recognised in the region during the second third of the last century, and they were studied subsequently by means of detailed biostratigraphic sections (Viallard, 1966, 1968; Meléndez, 1971). In the North of the Serranía de Cuenca Mountains, the Wealden facies are dominated by conglomerates, sandstones, shales, marlstones, lacustrine limestones and lignites (Meléndez, 1971; Ramírez and Meléndez, 1972), frequently containing vertebrate remains characterised by their variety and good preservation, similar to other well-known sites, such as Las Hoyas (Sanz et al., 1988, 1990; Buscalioni and Fregenal-Martínez, 2010), Buenache de la Sierra (Francés and Sanz, 1989; Buscalioni et al., 2008), Uña (Henkel and Krebs, 1969; Gómez et al., 2001), Carrascosa de la Sierra and Beteta (Francés and Sanz, 1989), and Masegosa (Sanz, 1985).

These heterolithic facies represent clastic sedimentation within a wide intra-basinal alluvial floodplain (Meléndez et al., 1989). Commonly, in Spain they were deposited in ephemeral streams with associated wetlands including swamps and peat bogs (Álvaro López and Olmo Zamora, 1989b), and are mostly of Barremian age. Specifically, the upper Barremian of the Serranía de Cuenca Mountains is represented by continental strata with no direct marine influence (Poyato-Ariza et al., 1998). It includes clays and sandstones of the El Collado Sandstone and Clay Formation (Vilas et al., 1982) and comprises the three new sites described here, and the coeval La Huérguina Limestone Formation (Vilas et al., 1982).

The El Collado Formation, with a markedly variable thickness $(0 \mathrm{~m}-200 \mathrm{~m})$, is composed mainly by arkosic sandstones and mudstones. The arkoses dominate the base of the formation and are heterometric (with highly variable size, but frequently conglomeratic), usually exhibiting trough and planar crossbedding. The mudstones may contain thin sandy micaceous interbeds, and generally predominate at the top of the formation (being in some areas the dominant lithology). Its age range has been determined from numerous studies, and ranges from the upper Hauterivian?/lower Barremian (Vilas et al., 1982), to the lower Barremian/basal Aptian (Álvaro López and Olmo Zamora, 1989b; Salas et al., 2001), and to the upper Barremian, on the basis of charophyte (Diéguez et al., 1995; Martín-Closas et al., 2009; Vicente and Martín-Closas, 2013) and ostracod (Schudack and Schudack, 2009) studies. This formation is interpreted as representing terrestrial alluvial or deltaic plains and fans (Vilas et al., 1982). Specifically, it would correspond to proximal alluvial floodplains crossed by narrow braided channels, and medium to distal wet fan-deltas with sporadic sandy streams, and mud flats with scarcely developed drainage. This palaeoenvironment included scattered ponds, small shallow lakes and palustrine marshy areas, fed by superficial stream and groundwater. It underwent seasonal floods followed by slow draining and evaporation, and a final seasonal period of desiccation (Buscalioni et al., 2008).

The El Collado Formation overlies discordantly (by angular unconformity) marine Jurassic or occasionally Triassic (Keuper facies) units or, concordantly (by erosive disconformity) the Aldea de Cortés Formation (Vilas et al., 1982), of non-marine siliciclastic origin. This lithostratigraphic unit is imprecisely estimated as of Valanginian-Hauterivian age. The El Collado Formation is separated by another erosive disconformity from the overlying Utrillas Sandstone Formation (sensu Fallot and Bataller, 1927; Aguilar et al., 1971), attributed to the Albian-lower Cenomanian, with numerous 
channel structures with trough and planar cross-bedding and very few fossils, organised in fining upward sequences usually interpreted as deposited on sandy alluvial plains crossed by braided channels and deltas with tidal influence (Capote et al., 1982). The El Collado Formation disappears laterally by nondeposition, by erosion, or by lateral facies change to the coeval La Huérguina Formation (Vilas et al., 1982). Both of these units follow a NE-SW direction. The alluvial siliciclastic deposits of the El Collado Formation occupy the marginal (and septentrional) belts of the Serranía de Cuenca Mountains, while the La Huérguina Formation is widespread in its central (and meridional) areas. This unit consists of different calcareous facies deposited in distal alluvial and lacustrine environments (Buscalioni et al., 2008).

Lithologically a similar sequence belonging to the El Collado Formation is seen in the three new sites reported here. It consists, from base to top, of 5-15 $\mathrm{m}$ of brown mudstones (B level), 8-18 m of grey mudstones ( $\mathrm{G}$ level) and $>4 \mathrm{~m}$ of red clays ( $\mathrm{R}$ level) separated by gradual boundaries, but with certain differences in each outcrop (Fig. 2). The sequence in Vadillos-1 displays calcareous nodules in its middle part, and calcarenites and limestones interbedded with oncolitic sandy banks towards the top of the $G$ level. The sequence in Vadillos-2 is incomplete in its lower part, and has more carbonate interbeds, such as a bed of $1,50 \mathrm{~m}$ of sandy limestones in the upper part of the G level. At El Tobar, the sequence shows in its upper part numerous channels built up of sandy banks, with trough and planar cross-bedding. The fossiliferous intervals ( $G$ and base of the $R$ levels) of these three sites include diverse remains with charophytes, ostracods, fishes, turtles, crocodyliforms and dinosaurs, among others (Figs. 1.3-8 and 2).

The fossiliferous muddy sequence described above overlies in Vadillos-1 and Vadillos-2 a well-marked discordance (López Olmedo and Gállego Coiduras, 1976) upon the Lower Jurassic Cerro del Pez Marl Formation (Goy et al., 1976) and Barahona
Bioclastic Limestone Formation (Goy et al., 1976), specially well exposed in the anticline at the former site. These strata contain foraminifers, ostracods, brachiopods, molluscs and echinoderms of marine carbonate platform facies, displaying a shallowing upward tendency (Álvaro López and Olmo Zamora, 1989b). Contrastingly, at El Tobar, the fossiliferous sequence overlies upper Barremian lacustrine limestones with charophytes, ostracods and vertebrate remains of the La Huérguina Formation that is separated from the El Collado Formation by a sharp boundary. At all three new sites, the fossiliferous sequence is separated from the overlying AlbianLower Cenomanian Utrillas Formation by a sharp erosive contact, representing a minor disconformity.

\section{Material and methods}

A comprehensive survey of all the three sites yielded a relatively high diversity of large vertebrate remains. Sediment samples were collected at different points of the mudstone sequence, focusing mainly on horizons with abundant organic matter. Sampling size varied depending on the locality, being approximately $75 \mathrm{~kg}$ at Vadillos- 1 and $30 \mathrm{~kg}$ at Vadillos-2 and El Tobar. The sediment was washed at the Departamento de Paleontología of the Universidad Complutense de Madrid (UCM) and passed through a sieve of $0.5 \mathrm{~mm}$ mesh size. It was dried and sorted for small fossils (charophytes, ostracods, fish scales, teeth, eggshell fragments, and any other small remains) under binocular stereomicroscope. Charophytes and ostracods were photographed, respectively, at the Serveis Cientificotècnics of the Universitat de Barcelona and the Sgiker Service of the Universidad del País Vasco/Euskal Herriko Unibertsitatea, using scanning electron microscope (SEM). Small vertebrate and eggshell images were obtained at the Departamento de Paleontología under binocular stereomicroscope. All the specimens described here are accessioned in the collection of the Departamento de Paleontología at UCM.
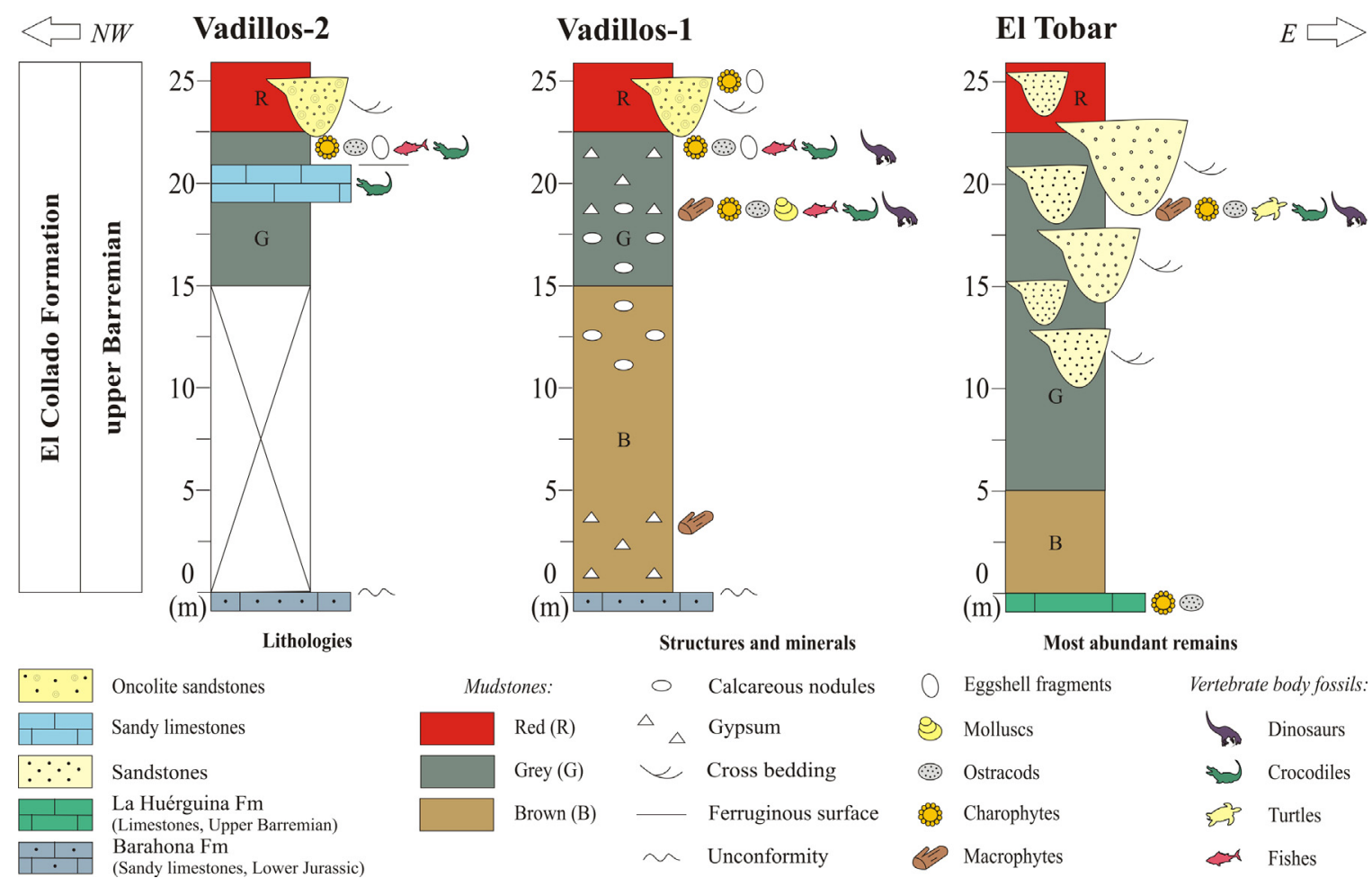

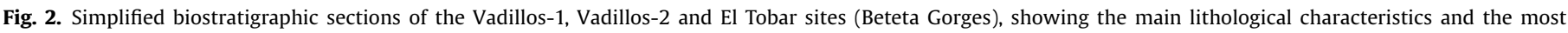
abundant remains, including vertebrate body fossils and others. Approximate locations of the three represented sections can be observed in Fig. 1.2 . 


\section{Taphonomy}

Micro and macroremains from different taxa have been recovered from the three studied sites (Vadillos-1, Vadillos-2, El Tobar). Within the fossil sample, different modes of preservation (with biostratinomic and diagenetic particularities) have been observed not only taking into account their taxonomical attribution (plants, invertebrates, vertebrates), but also their original location (different outcrops, stratigraphic levels).

Plants are usually preserved as carbonified remains (some with well-preserved microstructure) in the case of woody macrophytes (Fig. 3.1), or as carbonate remains in the case of charophytes (sensu Fernández-López, 2000). Ostracods and some molluscs have been recovered as carbonate (calcite) shells. However, most of the bivalves and gastropods are represented by internal and external moulds, have become preserved by authigenic preservation (sensu Schopf, 1975) (Fig. 3.2). Many different vertebrates (fishes, amphibians, turtles, crocodyliforms and dinosaurs) have been recovered as micro and macro-remains. They can be attributed to the duripartic mode of preservation (Schopf, 1975), in which only harder and more robust parts are preserved (scales, teeth, plates, axial or appendicular bones, osteoderms) (Fig. 3.3).

Each outcrop presents some differences in the main mode of fossil preservation. Generally, vertebrate remains in Vadillos-1 and Vadillos- 2 are notably less scattered and less fragmented (indeed, some fossils from these localities have been collected unbroken), than in El Tobar. At Vadillos-1, micro and macroremains are relatively well preserved (Cambra-Moo et al., 2014), with no significant taphonomic alterations being observed and micro anatomical characteristics of preserved tissues are usually visible (Fig. 3.3). Macro-remains (generally of dark grey to brown or orange colour, with some areas of limonitization) are mostly of decimetric size. Some of the plant, invertebrate and vertebrate remains occur within calcareous nodules of mudstone matrix (Fig. 3.4). At Vadillos-2, macro-remains are also well preserved, but they show a distinctive colouration, generally being whitish, due probably to carbonate enrichment during diagenesis. Finally, at El Tobar, numerous poorly preserved and scattered macro-remains
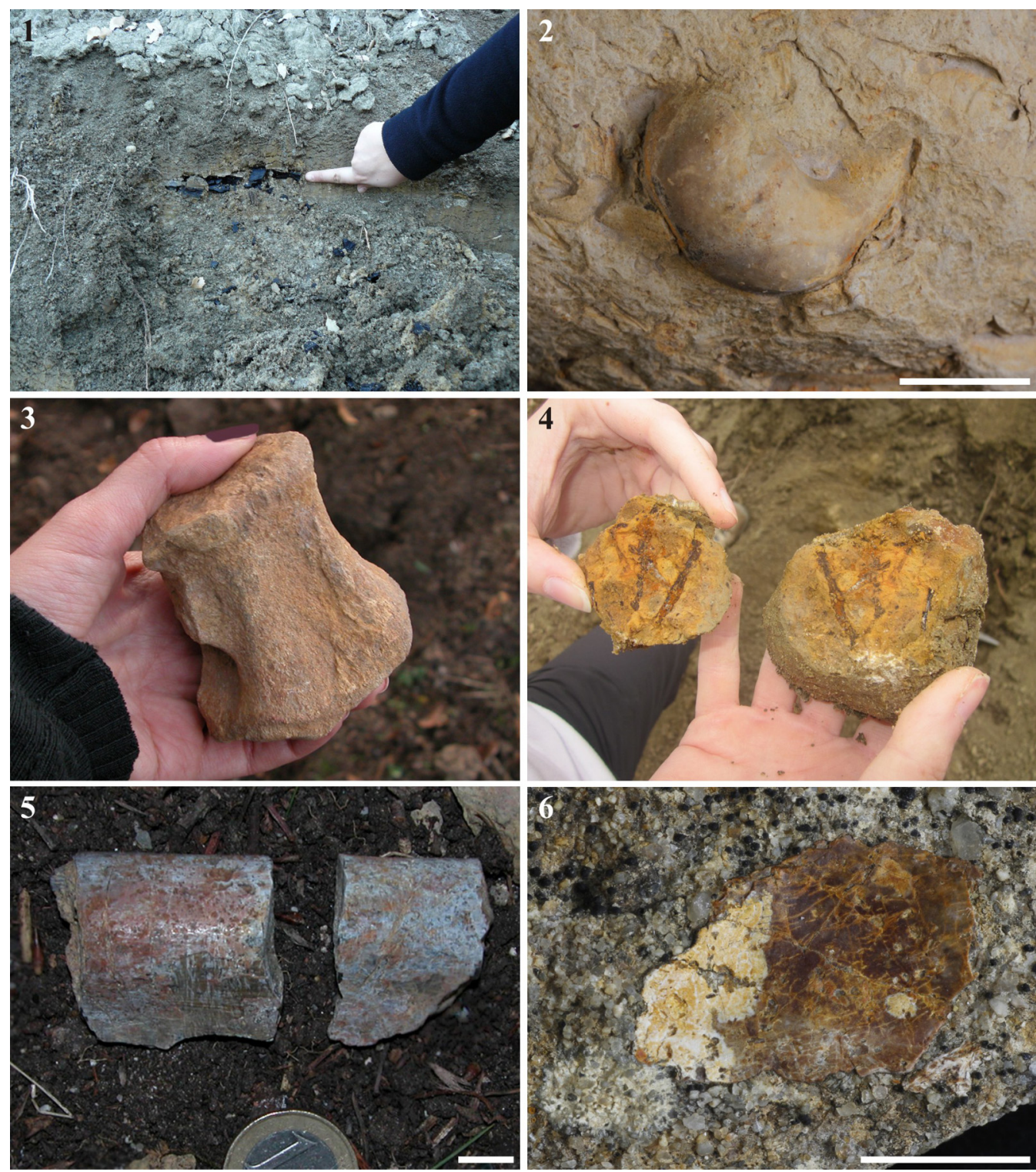

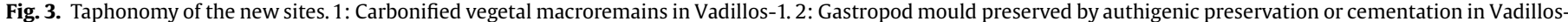

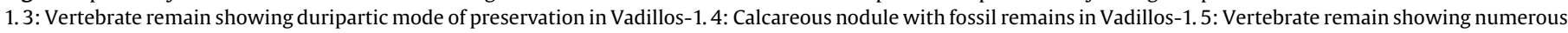
fractures in El Tobar. 6: Turtle plate fragment poorly preserved by duripartic mode in El Tobar. Scale bars are $0,5 \mathrm{~cm}$. 
have been collected. Most of the macro-remains recovered at this site exhibit fractures and structural deformation, probably due to the effects of transportation and pressure during the fossilization process (Fig. 3.5-6).

\section{Fossil content}

Samples collected for microfossils from the three sites have yielded charophytes, ostracods and microvertebrate remains (e.g., scales, teeth), providing important taxonomic, chronological and palaeoenvironmental information (Fig. 2; Appendix A). The microvetebrates from these localities include fishes, turtles, crocodyliforms and dinosaurs. Particularly, at Vadillos-1 numerous plant macrofossils have been found, along with bivalves and gastropods, as well as abundant microvertebrates. Isolated bones have been also found on the outcrop surface, and include vertebrae, ribs, osteoderms and others, most of which can be assigned to Dinosauria. At both this site and Vadillos-2, the abundance of small bony fish scales and teeth, crocodyliform teeth and eggshell fragments is noteworthy. At El Tobar, osteichthyan remains are scarcer, whereas turtle shell bones are distinctly more abundant, and crocodyliforms and dinosaurs are relatively abundant also.

\subsection{Plants (macrophytes, charophytes)}

Plant remains consist mainly of carbonified wood (seemingly portions of axes), and occur most frequently in level $\mathrm{G}$ at Vadillos-1, along with abundant charophyte fructifications (Figs. 3.1, 4.1-3). In detail, the charophyte assemblage comprises A. trivolvis triquetra, Globator maillardii trochiliscoides and Clavator harrisii harrisii. The former two species occur all in three localities whereas the latter species, to date has only been found at Vadillos- 2 . However, the nature of this assemblage may have been biased by the large sieve mesh size employed. A. trivolvis triquetra (Fig. 4.1) is an atopocharoid clavatoracean represented by large utricles with characteristic tri-radiated symmetry formed by repeatedly trifurcating branches (Grambast, 1968). Another atopocharoid is G. maillardii trochiliscoides (Fig. 4.2). This utricle is also triradiated in the origin of the lineage Globator (Berriasian morphotypes) but younger forms display a highly spiralised structure that makes the triradiated symmetry difficult to recognise. Some of the utricles display a general morphology reminiscent of Globator maillardii biutricularis, however the basal features correspond well to G. maillardii trochiliscoides (Grambast, 1966). Finally, C. harrisii harrisii (Fig. 4.3) is a clavatoroid clavatoracean showing two characteristic opposed fans of bract-cells, as indicated by Peck (1941). Biostratigraphically, this assemblage is comparable with that described from the laterally equivalent La Huérguina Formation by Vicente and Martín-Closas (2013), which belongs to the Ascidiella cruciataPseudoglobator paucibracteatus biozone.

\subsection{Ostracods}

The ostracod assemblage is mostly composed of species Cypridea (Fig. 4.4-6). Numerous specimens of Cypridea gr. modesta, Cypridea cf. C. isasae, Cypridea sp. aff. C. moneta, and Cypridea sp. 1 have been identified. Another species, Cypridea sp. 2, with poorly preserved (not figured) and very large shells $(\mathrm{L}=2.86 \mathrm{~mm}$ ) showing normal overlap, smooth surface and small-rounded rostrum, is also present. Some representatives of Mantelliana sp. (also poorly preserved and not figured) have been identified in the ostracod assemblage.

\subsection{Molluscs (bivalves, gastropods)}

Bivalves and gastropods occur at Vadillos-1 (Fig. 5.1-4). The most representative and complete bivalve is $4 \mathrm{~cm}$ wide and $2 \mathrm{~cm}$ long (Fig. 5.1), inequilateral, compressed, with suboval contour, and has several concentric growth lines on its surface. These features correspond to those of the Unionoida. The remaining bivalve specimens consist of incomplete fragmented internal moulds, and also probably are unionids. All gastropods are preserved as internal moulds of between $1-2 \mathrm{~cm}$ high and $0.5-$ $2 \mathrm{~cm}$ wide (Fig. 5.2-4). The shell is turbiniform, with 3-4 whorls of rounded margins, spiral lines of the whorls visible in internal mould, and the body whorl bigger and more expanded than the others, as is characteristic of the Viviparus.

\subsection{Vertebrate microfossils (fish scales and teeth, amphibian and reptile teeth, eggshells)}

All microvertebrate fossils were recovered by sieve-washing sediment samples and are therefore disarticulated elements. Fish remains are present at the three sites, and are mainly represented by ganoid scales, teeth and some bone fragments. No vertebrae have yet been found. Scales are relatively abundant at Vadillos- 1 and Vadillos-2. All are of rhombic outline, with thick ganoin and lack ornamentation, coinciding with the morphology displayed by semionotiform fishes, well represented in many Lower Cretaceous sites. Variations in shape reveal provenance from the anterior, middle and posterior regions of the fish (Figs. 5.5-6). Fish teeth of two different morphotypes are also present in these assemblages (Figs. 5.7-9). The most common morphotype corresponds to hemispherical tooth crowns, with a wide circular base, the cusp covered by shiny, smooth enamel and rarely display any type of wear. This morphology is common in semionotiform fishes. The second morphotype is represented by a few conicstyliform teeth without striae or crests on the anterior and distal edges.

Amphibians are known from a couple of minute dentary fragments with non-pedicellate tricuspate teeth set in a row, found in Vadillos-1. They have been tentatively assigned to Albanerpetontidae (Fig. 5.10). Reptile remains are the most common small-sized vertebrate fossils at the three sites, comprising teeth and bone fragments. Most of the teeth can be assigned to one of two basic morphotypes, although a third morphotype has also been identified, represented by very few remains. The first morphotype (Figs. 5.11-12) consists of small molariform, bulbous teeth, with a low crown and elliptical or even kidney-shaped to subcircular cross-section. Longitudinal, wellmarked ridges cover both the lingual and the labial sides of the crown, and the apex usually displays some degree of wear. These teeth are the most abundant in the three Beteta sites and resemble those assigned to Bernisartiidae? crocodylomorphs in La Cantalera (Puértolas-Pascual et al., 2015), although the more triangularshaped morphology has not been found until now in the Beteta sites. A second morphotype (Fig. 5.13) consists of small conical teeth, rarely over $2 \mathrm{~mm}$ in height, with a sub-circular to circular cross-section and high crown with acute apex. Longitudinal ornamentation on the crown shows widely spaced thick ridges, both on the lingual and the labial sides. A distinct smooth carina is seen on the anterior and posterior edges of the crown. These teeth resemble strongly those assigned to Goniopholididae? crocodylomorphs in La Cantalera, Spain (Puértolas-Pascual et al., 2015). A few teeth resembling in shape to those assigned to Theriosuchus (Atoposauridae) in La Cantalera and Buenache de la Sierra have also been found. The crown is lanceolate-shaped, slightly constricted at the base, with elliptical section and mesial and distal carinae, both labial and lingual surfaces are ornamented with longitudinal ridges (Fig. 5.14). However, these teeth differ in having smooth carinae and practically straight ridges rarely fused, inbetween the longer ridges shorter ridges occasionally appear both near the base of the tooth as next to the carinae. Eggshell fragments 
(Figs. 5.15-16) are very numerous, all of them preserved as small fragments rarely reaching $3 \mathrm{~mm}^{2}$. These fragments differ in thickness and surface ornamentation and are assigned to at least three different morphotypes, one with a distinct crocodylomorph pattern.
7.5. Vertebrate macrofossils (turtle plates, crocodyliform bones and osteoderms, dinosaur bones)

The macrovertebrate assemblage comprises remains of turtles, crocodyliforms and dinosaurs (ankylosaurs, ornithopods and theropods). The turtle remains include some indeterminate
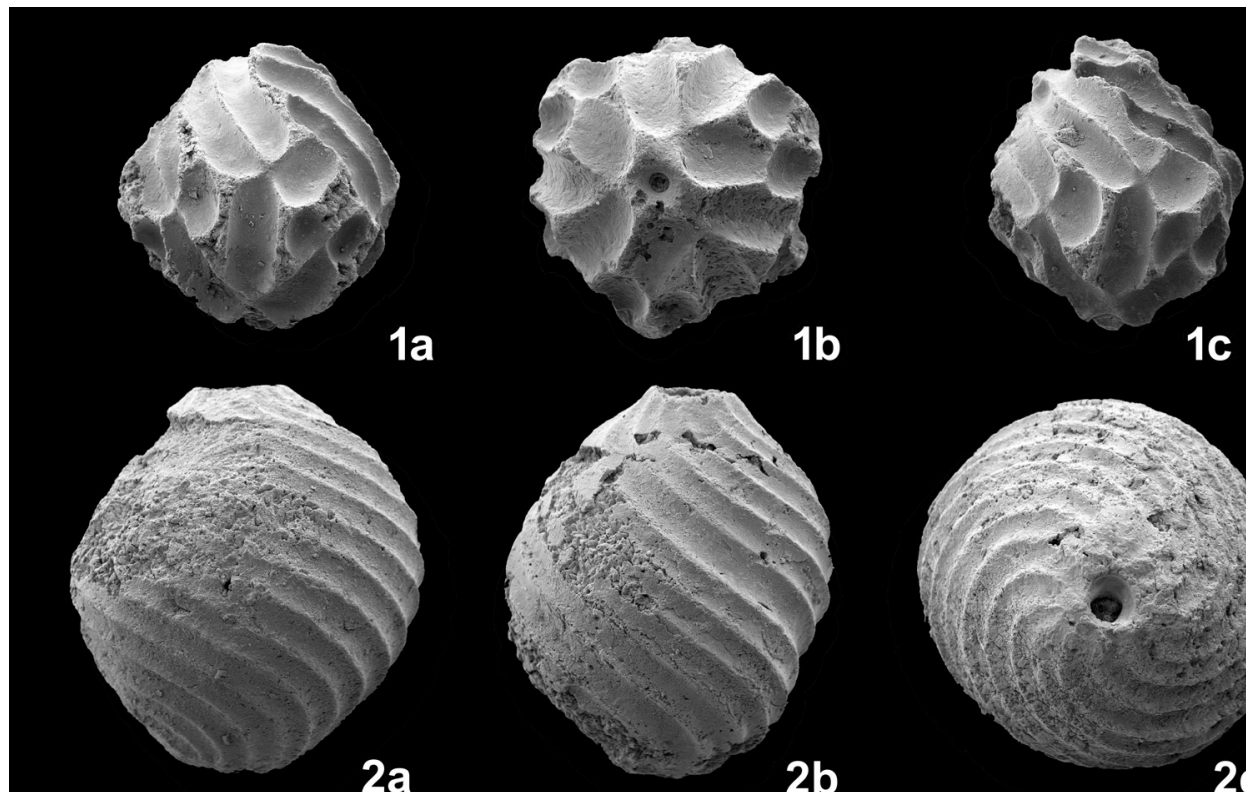

$1 \mathrm{C}$

$2 a$

$2 b$
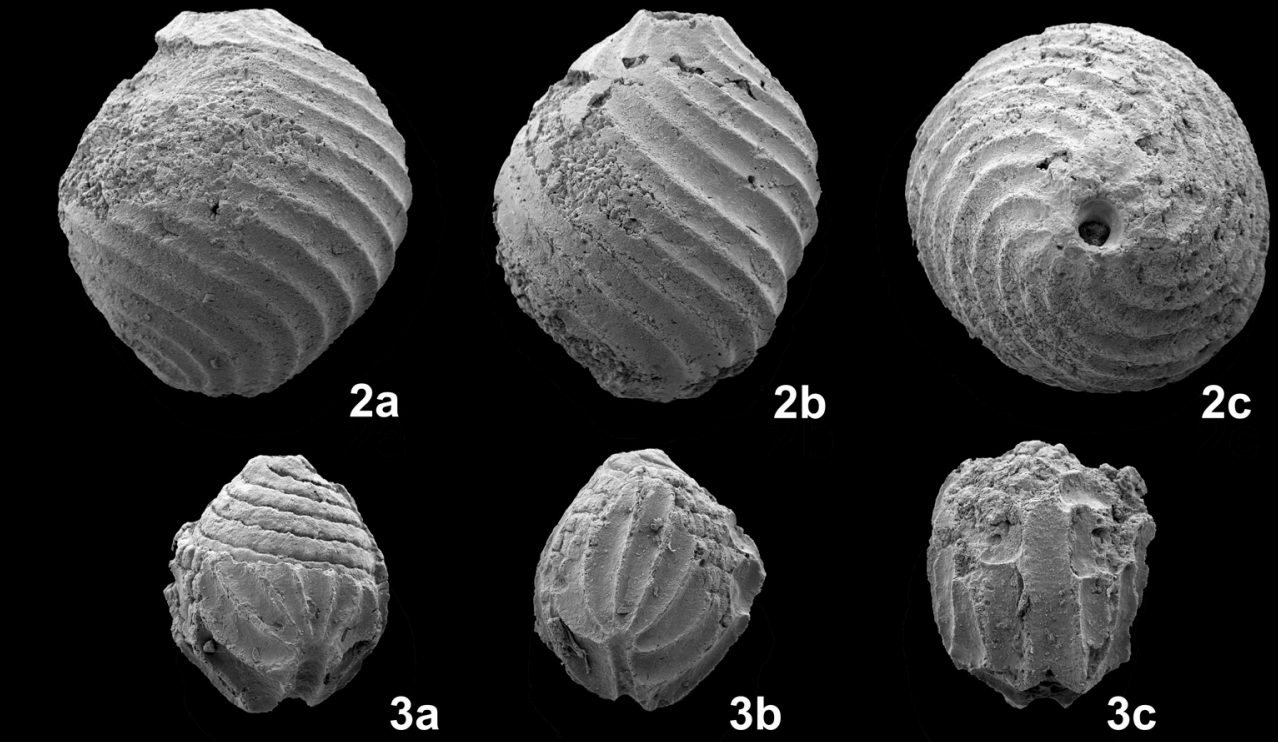

2c

\section{$3 a$}

$3 b$

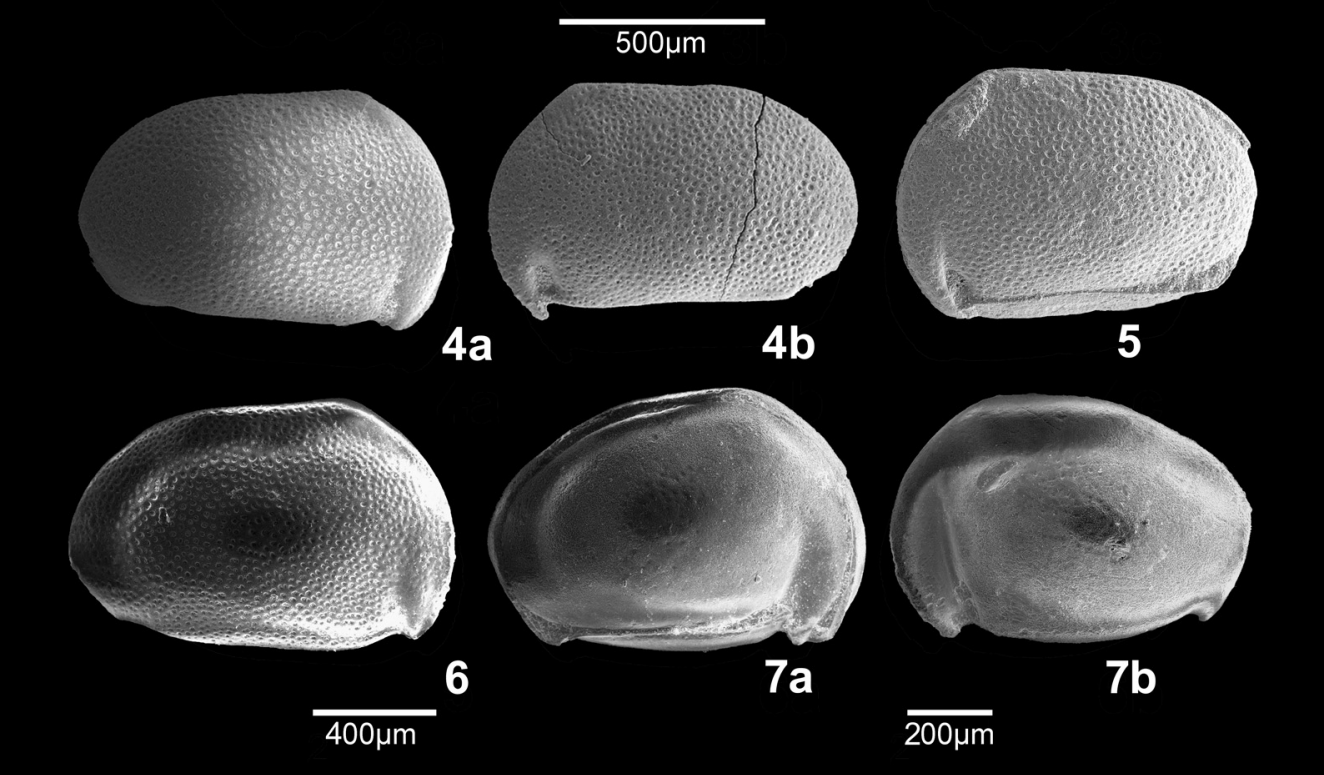

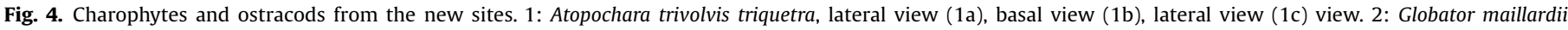

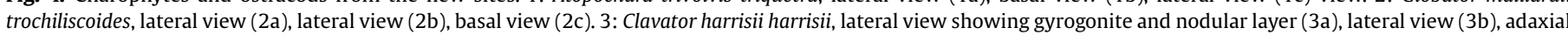

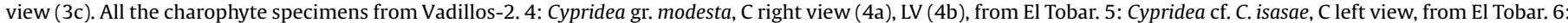

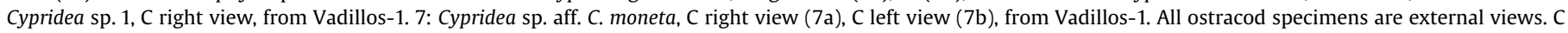
carapace, LV left valve. Scale bars are $500 \mu \mathrm{m}$ for $1-3,400 \mu \mathrm{m}$ for $4-5$, and $200 \mu \mathrm{m}$ for 6 . 


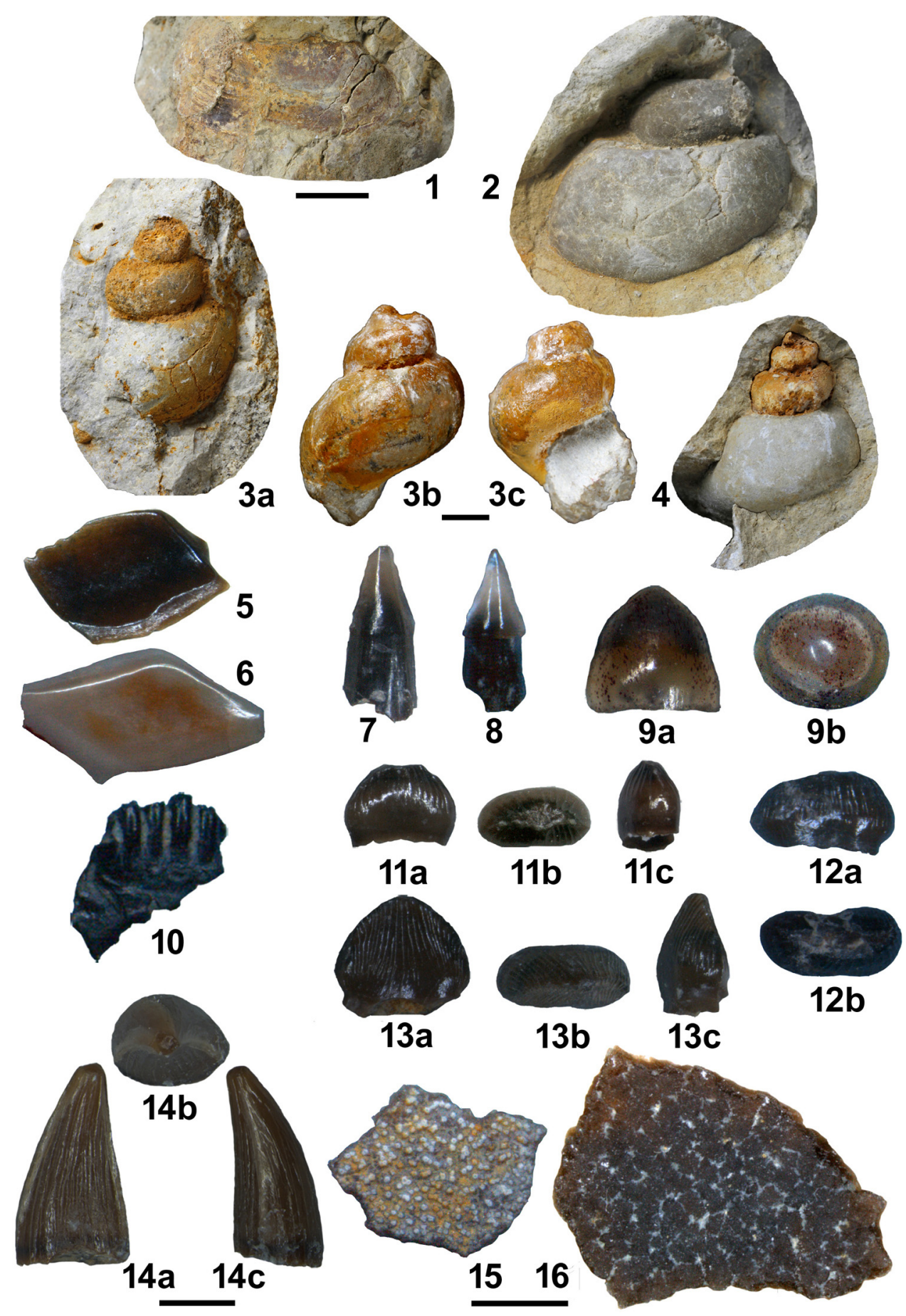

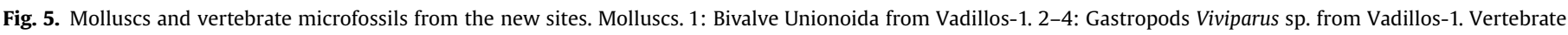

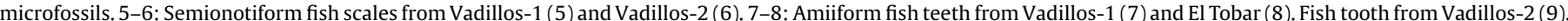

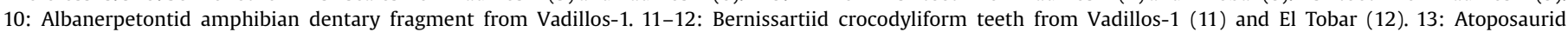

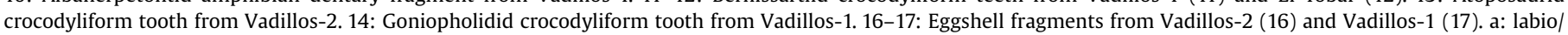
lingual view; b: apical view; c: antero/distal view. Scale bars are $2 \mathrm{~cm}$ for $1,1 \mathrm{~cm}$ for 2-4, $1 \mathrm{~mm}$ for 5-9, 11-13 and $15-16$, and $0,5 \mathrm{~mm}$ for 10 and 14 .

fragments corresponding to shell plates of at least one taxon (Fig. 6.1-2). The shell bone structure composed of interior cancellous bone framed by external and internal compact layers allows attribution to Chelonia (Scheyer, 2007).

Crocodyliforms are represented by fragments of osteoderms and the centrum of a amphicoelous postaxial cervical vertebra (Fig. 6.3-4). The cervical vertebra lacks the complete neural arch that is detached at the level of the neurocentral suture, which probably had not fully fused. The anterior and posterior articular facets of the centrum have a sub-quadrate outline and are about as high as they are wide. In side view, the ventral contour of the centrum is concave, mainly due to the ventral projection of the posterior articular surface. An anteroposteriorly elongate parapophysis is located in the ventral part of the lateral face. There is no evidence of ventral hypapophysis, suggesting that the vertebra is a posterior cervical. The general aspect of the vertebra corresponds 

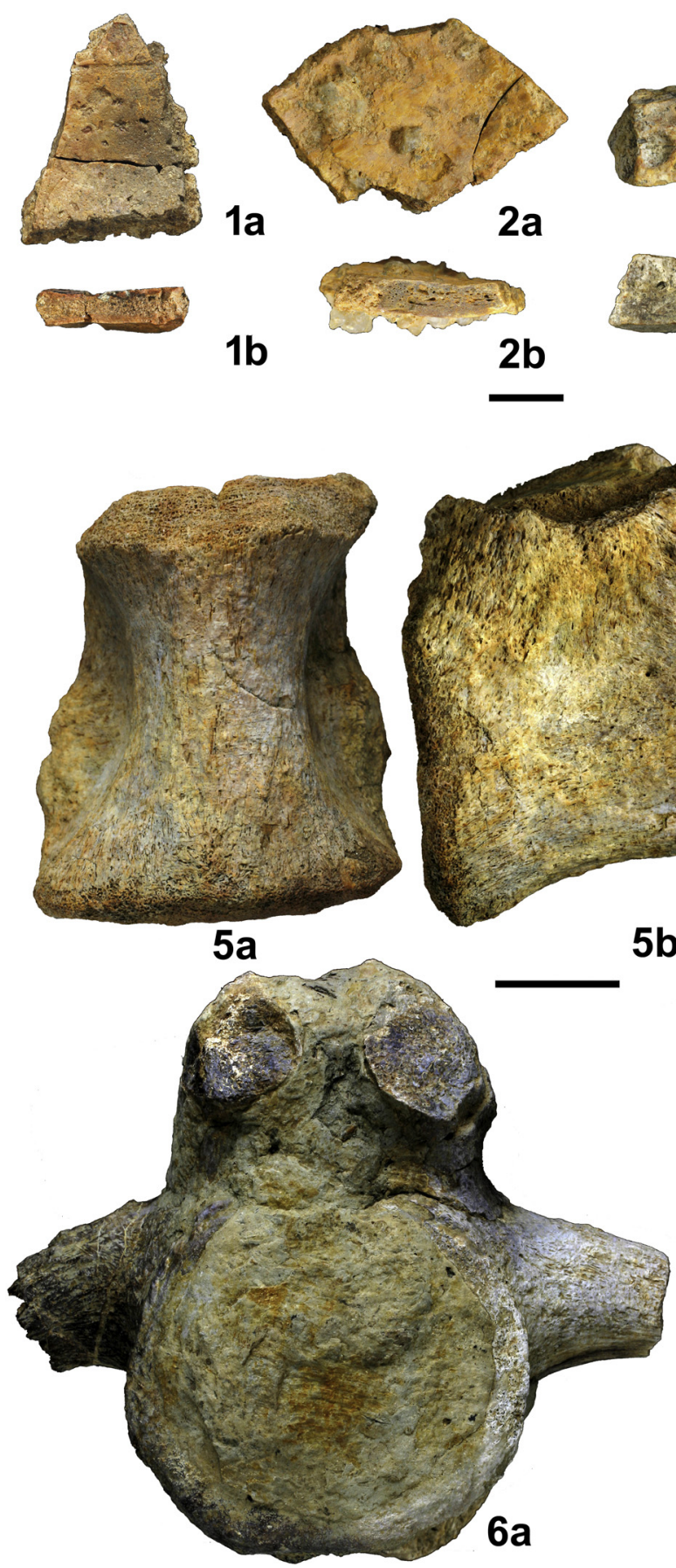

$2 a$
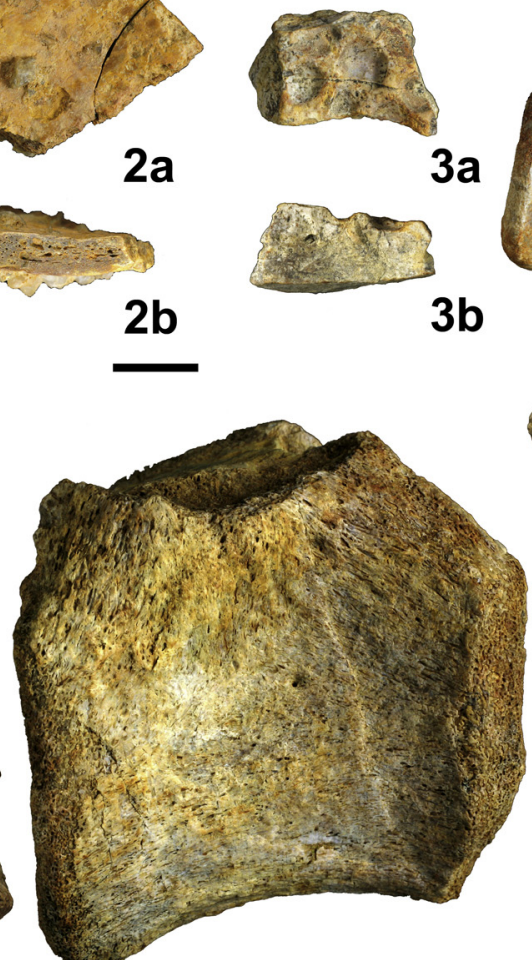

$5 b$

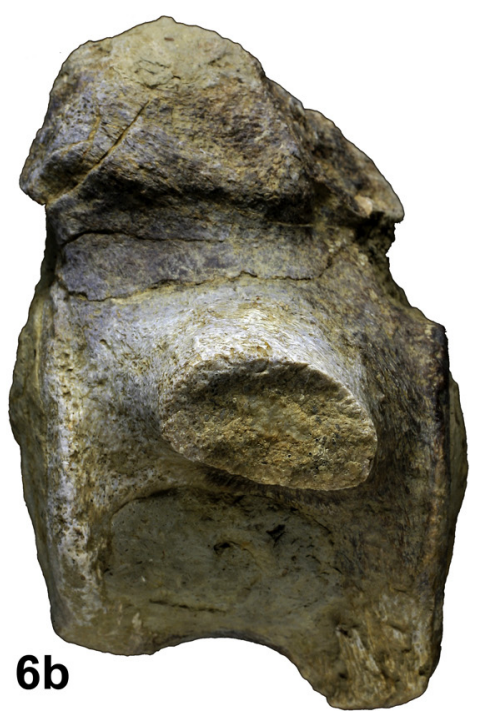

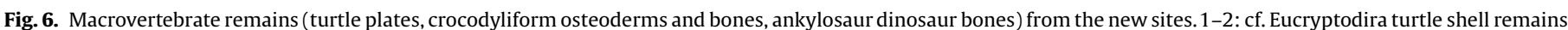

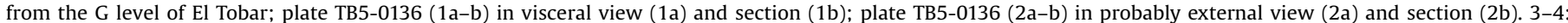

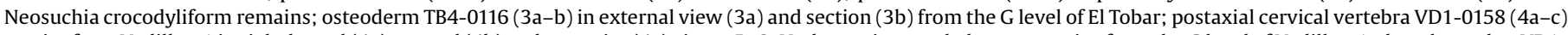

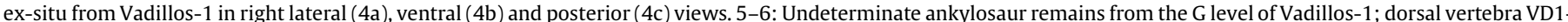

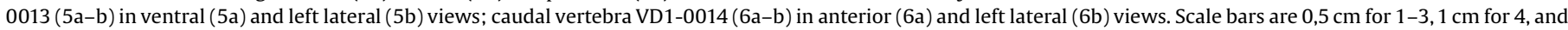
$2 \mathrm{~cm}$ for $5-6$.

to that of a basal neosuchian. Fragments of osteoderms are very incomplete and only can be recognised by their ornamentation of surface pits. These are also consistent with a neosuchian origin.

The dinosaur remains include isolated vertebral centra, neural arches and rib fragments, phalanges and an osteoderm, representing ankylosaurs (Figs. 6.5-6, 7.1), ornithopods and theropods. Ankylosaur material includes dorsal and caudal vertebrae and an osteoderm from Vadillos-1. An incomplete dorsal vertebra (Fig. 6.5) has an elongate centrum in which the articular facets are slightly amphicoelous. The margin of the posterior articular facet is eroded. The ventral surface of the centrum lacks a keel. The preserved part of the neural canal is large related to the centrum height. Only the basal part of the right transverse process is preserved. A nearly complete caudal vertebra (Fig. 6.6) is preserved, with the articular facets of the caudal centrum amphicoelous and slightly hexagonal. The ventral surface of the centrum bears a wide and deep longitudinal groove. The posterior haemal arch facet is strongly developed and the incomplete 
transverse processes directed laterally. The neural canal is almost circular and large and only the base of the prezygapophyses is preserved. A nearly complete caudal plate (Fig. 7.1), missing the top, has most of its surface covered by matrix. This plate is subtriangular, hollow-based and laterally flattened. The anterior margin is convex and is longer than the nearly straight posterior margin. The base, which is covered by matrix, is narrow and elongated.
Ornithopods are represented by three vertebral centra and a pedal ungual phalanx from small indeterminate forms (Fig. 7.2-5). A cervical vertebra and a sacral centrum were recovered from Vadillos-1. The cervical centrum (Fig. 7.2) is strongly opisthocoelous with a large and hemispherical anterior articular condyle. The posterior cotyle is deeply concave and its width is greater than the height. Ventrally the centrum bears a longitudinal keel. Dorsally the neural canal is narrow in the middle of the centrum and the
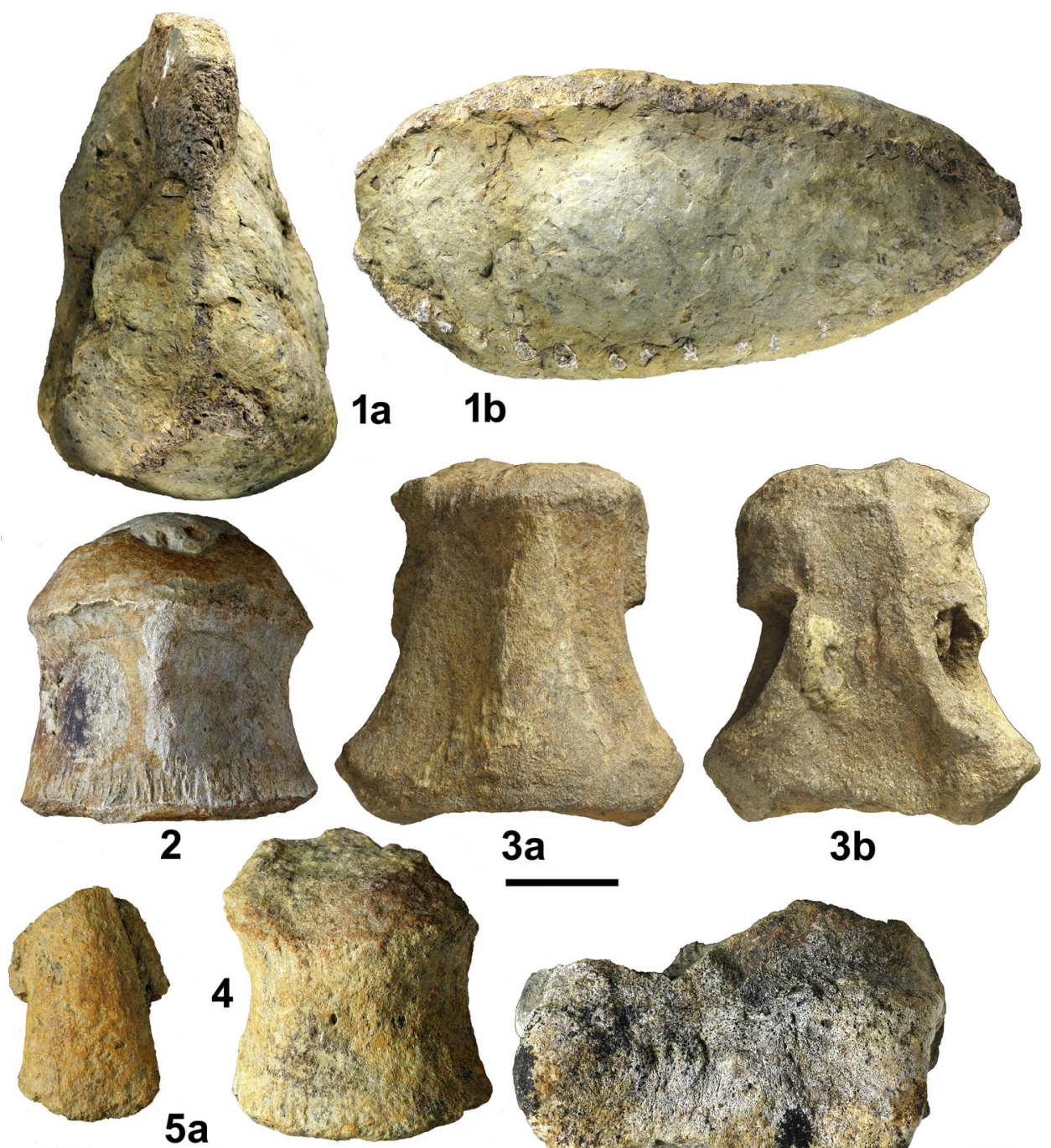

$3 b$
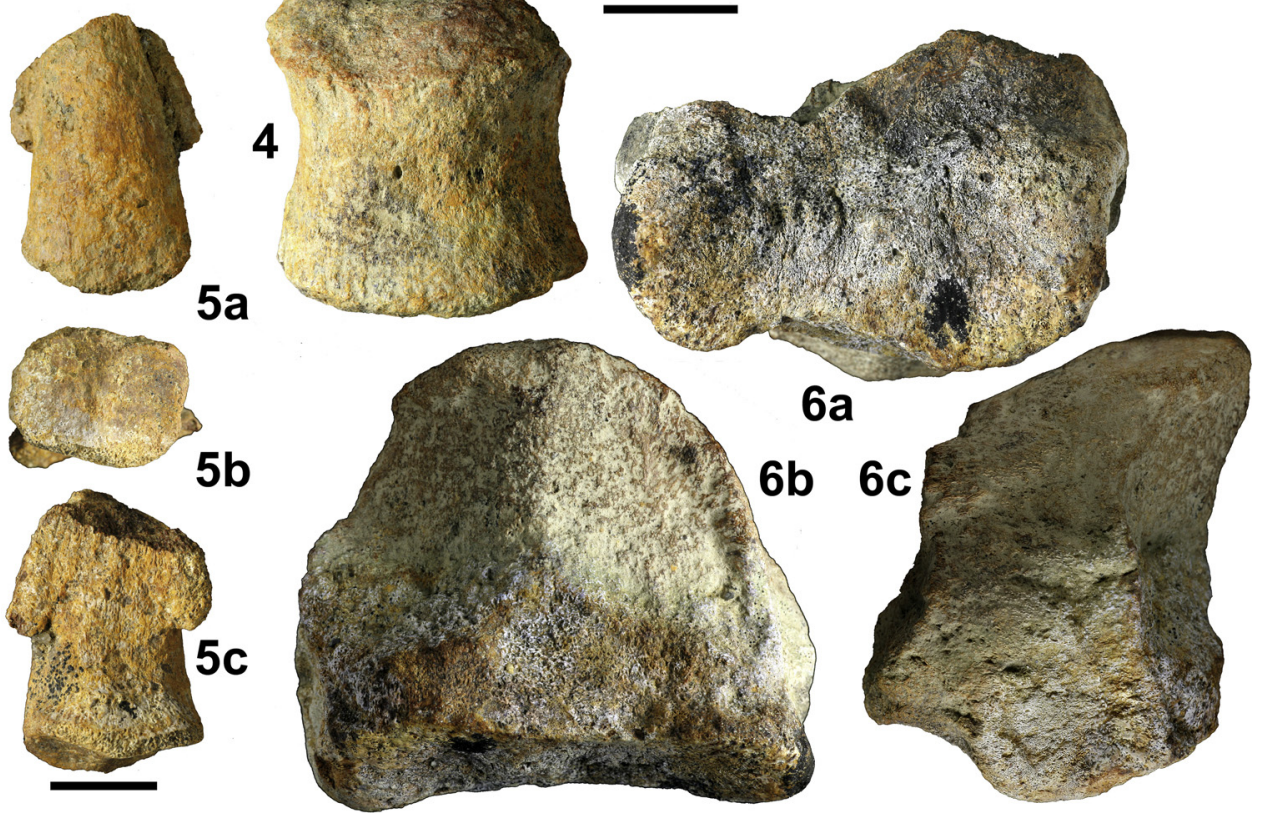

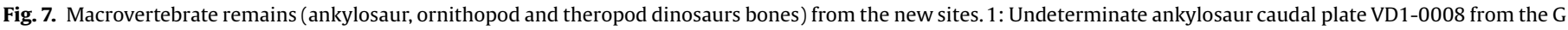

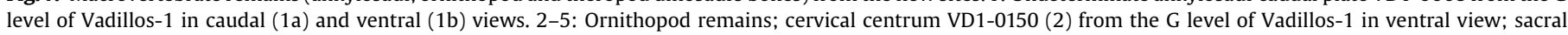

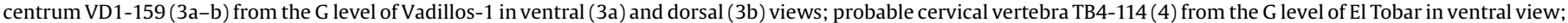

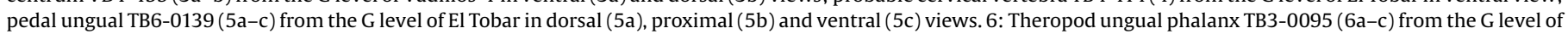
El Tobar in ventral (6a), proximal (6b) and left lateral (6c) views. Scale bars are $2 \mathrm{~cm}$ for $1-4$ and 6 , and $1 \mathrm{~cm}$ for 5 . 
area for the suture of the neural arch is clearly visible. Laterally the neurocentral suture is convex. The sacral centrum (Fig. 7.3) bears a median ventral keel, which is more strongly developed anteriorly. The anterior articular facet is flat to gently concave whereas the posterior articular facet is concave. The width of the anterior articular facet is greater than the height whereas in the posterior articular facet both measurements are nearly equal. The facets for the sacral ribs are large and located anteriorly. Posterior to the rib facets a large foramen is located in the middle of the centrum. A centrum from El Tobar (Fig. 7.4) probably corresponds to a cervical vertebra. The anterior articular facet is eroded but slightly convex whereas the posterior cotyle is concave. Both articular facets are oval with the greater diameter transversely. The ventral surface is transversely convex and has no keel. Dorsally the neural canal is narrow in the middle and the insertion area for the neural arch is visible. The pedal ungual (Fig. 7.5) lacks most its distal end. This element is dorsoventrally flattened and bears medial and lateral grooves. The proximal articular surface is quadrangular and a vertical ridge divides the surface in two facets.

Finally, a rather incomplete, proximal portion of an ungual phalanx (Fig. 7.6) from El Tobar is the only element that could be assigned to the Theropoda. The proximal articular surface is triangular with the apex rounded. Despite the ventral part of the proximal articular surface is eroded a vertical ridge divides this surface in two sib-facets.

\section{Discussion}

A comprehensive analysis of the geological and palaeontological data obtained in the three new sites has enabled to carry out some interpretations concerning the sedimentary palaeoenvironment (and its age), and to characterise the identified vertebrate assemblage, enabling a preliminary comparison with other nearby upper Barremian fossiliferous outcrops.

\subsection{Sedimentary palaeoenvironment}

The charophyte assemblage identified in the three sites contains certain taxa that are good proxies both for the palaeoenvironment reconstruction and for dating purposes. In all of them, G. maillardii trochiliscoides, a species that thrived in shallow ponds located in well-drained palustrine areas (Vicente and Martín-Closas, 2013), is well represented. The same assemblage, with $A$. trivolvis triquetra, G. maillardii trochiliscoides and C. harrisii harrisii, is also is also useful for dating the El Collado Formation. This assemblage is basically the same that described in the laterally equivalent La Huérguina Formation, and belongs to the lower part of the Ascidiella cruciata-Pseudoglobator paucibracteatus upper Barremian-Lower Aptian biozone. Accordingly, its stratigraphic interval has been considered as upper Barremian by Vicente and Martín-Closas (2013), on the basis of previous studies on charophytes (Diéguez et al., 1995; Martín-Closas et al., 2009) and ostracods (Schudack and Schudack, 2009).

The presence of unionoid bivalves and the gastropod Viviparus confirms that the palaeoenvironment was predominantly freshwater (Aguirrezabala et al., 1985; Ruiz-Omeñaca, 2006; Delvene and Araujo, 2009). Bivalves of the Unionoida, similar to those described here, are frequent in other Spanish outcrops of Wealden facies (e.g., Ruiz-Omeñaca, 2006; Bermúdez-Rochas et al., 2006, 2013; Delvene and Araujo, 2009). Similarly, the gastropods of the family Viviparidae are considered as exclusive of freshwater ecosystems (Robles-Cuenca, 1986), with Viviparus widely recorded in different continental Lower Cretaceous sites of Spain (e.g., Calzada Badía, 1977; Viera and Torres, 1996; Ruiz-Omeñaca, 2006; Delvene and Araujo, 2009; Delvene and Munt, 2011; Delvene et al., 2013). The ostracod species identified in the Beteta sites (mainly
Cypridea gr. modesta, $C$. cf. isasae, and C. aff. moneta) also agree with the type of environment and the age indicated by the charophyte and the mollusc assemblages. These ostracod taxa are linked to freshwater terrestrial palustrine palaeoenvironments, though with the particularity of being tolerant of occasional influence of slightly saline waters (Horne, 2002). As a whole, Cypridea assemblages are characteristic of non-marine sediments of the Lower Cretaceous of the Tethys (Horne, 2002; Schudack and Schudack, 2009).

The palaeoenvironment indicated by the fossils found from these sites fits well with the results obtained from the analysis of the depositional environment from the sediments. Consequently, the sedimentary palaeoenvironment proposed here for the new sites corresponds to an upper Barremian alluvial-palustrine floodplain crossed by braided sandy channels, as is characteristic for the El Collado Formation. Nevertheless, the strong freshwater influence (determined from the charophyte, mollusc and ostracod assemblages) underwent important variations in water level and energy, causing occasional increase in salt concentration, probably related to the strong seasonality in palaeoclimatic dynamics of the region (Fregenal-Martínez and Meléndez, 1993, 2000; FregenalMartínez, 1998; Fregenal-Martínez and Buscalioni, 2009). Initially, the palaeoenvironment was possibly flooded, forming muddy swamps relatively rich in plant and animal organic matter (reducing conditions: B and G levels of Fig. 2) and locally, carbonate ponds (nodules and sandy limestones). Subsequently, these swamps and ponds were partially or totally desiccated by a gradual drop of ground water levels, suffering subaerial exposure and development of pedogenetic processes (oxidising conditions: $\mathrm{R}$ levels). This general depositional pattern was somewhat different at the three sites, varying from a sedimentation of a more carbonate nature in Vadillos-2 to a more sandy nature in $\mathrm{El}$ Tobar. These differences seemingly depended on the proximity of each fossil locality to the distributary channels, being farther from them in Vadillos-2 and closer in El Tobar.

A similar sequence commencing with darker sediments due to reducing conditions that change progressively towards the top to red levels with oxidant conditions, is also seen in other Lower Cretaceous sites. This sedimentary change has been interpreted in palaeoenvironmental terms as a gradual decrease of the drainage in a proximal-distal direction within alluvial-lacustrine environments (e.g. Wright, 1999; Wright et al., 2000). It also fits with the model proposed by Peropadre and Meléndez (2004) for the Lower Cretaceous of the Altomira Range, found to the West of the Beteta Gorges. A similar palaeoenvironmental interpretation is provided by Gierlowski-Kordesch et al. (1991) and Gómez-Fernández and Meléndez (1991) for the contemporary material at the South of the Serranía de Cuenca Mountains, which differs by having a more carbonate sedimentation, mainly composed by rhythmically laminated lacustrine limestones of the La Huérguina Formation. The existing palaeoenvironmental differences between El Collado and La Huérguina formations is evident through the palaeontological content from the sites located in these two formations, particularly in the ostracod assemblages (Schudack and Schudack, 2009). Palaeogeographically, the new sites presented in this paper (Northern part of the Serranía de Cuenca Mountains) and those located to the West (Altomira Mountains: Meléndez, 1971) could correspond, respectively, to the NE and to the W alluvial-palustrine margins of the Uña-Las Hoyas Trough (Southern part of the Serranía de Cuenca Mountains: Meléndez et al., 1989), where increased subsidence was located in the lacustrine basin of Las Hoyas (Fregenal-Martínez and Meléndez, 1993, 2001; FregenalMartínez, 1998). This relatively deep subsiding basin included the regional depocenter where most of the remaining upper Barremian vertebrate sites of the Serranía de Cuenca Mountains are located (Las Hoyas, Buenache de la Sierra, Uña, with a common palaeoecological structure: Buscalioni et al., 2008). 


\subsection{Vertebrate assemblage}

Microvertebrate results must be considered preliminary considering the low volume of sediment processed by sieving. Nevertheless, the number of small vertebrate fossils obtained in the samples from the three new sites, particularly Vadillos-1, indicates a richness and diversity similar to that described from the nearby and contemporary locality of Buenache de la Sierra (Buscalioni et al., 2008) and higher than that reported from other Lower Cretaceous outcrops, such as Galve (Canudo et al., 1997; Ruiz-Omeñaca et al., 2004) and La Cantalera (Ruiz-Omeñaca et al., 1997; Canudo et al., 2010), both in the Teruel Province (Spain), from which several tonnes of sediment were sieved to retrieve small vertebrate remains. Though similar major taxonomic groups are represented in the Buenache de la Sierra and the Beteta sites, differences in particular taxa or in relative abundances have been observed. Some of the fish remains described in Buenache de la Sierra have not been found yet in the Beteta sites, particularly vertebral centra and some tooth morphotypes (3 and 4 of Buscalioni et al., 2008), all of which are poorly represented in the Buenache de la Sierra assemblage. The most common fish teeth in the Beteta sites might correspond to morphotype 2 of Buenache de la Sierra, but differs in being smaller and with a less swollen appearance than those figured by Buscalioni et al. (2008). Eggshell preservation also seems to be slightly different in Buenache de la Sierra, where fragments are apparently larger but rarer than in Vadillos-1. Since taxonomic assignment of these remains is still pending, no comparisons concerning diversity of eggshell morphotypes may be given. The assemblage of Buenache de la Sierra contains additional small vertebrate fossils represented by single or very few remains that have not been found as yet in the Beteta sites, such as pterosaurs or mammals. However, none of the differences between the two sites mentioned above may be considered definitive until more microvertebrate material is processed from the Beteta sites.

In the nearby Teruel Province a number of Barremian sites with similar microvertebrate assemblages are known. New surveys conducted on Wealden outcrops are leading to the discovery of new sites, such as the Barranco del Hocino (Alonso et al., 2016), which, although in early stages of study, are providing further evidence of the existence of a certain uniformity in the taxonomical content of the Northeastern Spanish Barremian sites. All of them show a high diversity of small vertebrates, among which small crocodylomorphs are the most abundant. Compared to Spanish Basque-Cantabrian (Bermúdez-Rochas and PoyatoAriza, 2007; Delvene and Bermúdez-Rochas, 2009) and Southern Britain (Sweetman, 2006; Hooker and Sweetman, 2009; Sweetman and Insole, 2010; Sweetman et al., 2014) Wealden sites, the absence of Chondrichthyans and of marine bony fishes in the assemblages of Beteta marks an important difference, seemingly of palaeoenvironmental nature.

The observed macrovertebrate fossil assemblage (turtles, crocodyliforms and dinosaurs: ankylosaurs, ornithopods and theropods) is consistent with that reported in the surroundings by Lapparent et al. (1969), although sauropods are absent for the moment and ankylosaur remains are reported here for the first time in the Lower Cretaceous of Cuenca. The Iberian record of turtles includes primitive forms (Stem Testudines), as well as members of both Pan-Pleurodira and Pan-Cryptodira. The outer surface of the plates recognised in Beteta is smooth. Therefore, their attribution to the hitherto known representatives of the stem Testudines (Solemydidae) and Pan-Pleurodira (Dortokidae) in the European Lower Cretaceous record can be excluded. The absence of decoration also excludes a Paracryptodira origin for the material (Pleurosternidae) (Pérez-García, 2014; Pérez-García et al., 2015). However, this character is shared by many representatives of the
Eucryptodira, the most diverse group of turtles in the Iberian Lower Cretaceous record. In addition to taxa shared with other European regions (e.g., Chitracephalus, Brodiechelys), the Iberian record includes several forms so far recognised as endemic to this region (e.g., Camerochelys, Galvechelone, Hoyasemys, Larachelus) (PérezGarcía, 2012; Pérez-García and Murelaga, 2012a, 2012b, 2013; Pérez-García et al., 2012, 2014). These turtles correspond to both forms not attributable to Cryptodira as basal representatives of this lineage. Therefore, the turtle remains from the Beteta sites are identified here as cf. Eucryptodira, which is consistent with the European contemporary record.

The most common assemblage of crocodyliforms at the European Lower Cretaceous sites is mainly composed by scarce basal crocodyliforms and basal mesoeucrocodyles, and abundant derived neosuchian forms, usually closely related to Bernissartia, Goniopholididae and Atoposauridae (Buscalioni et al., 2008). Similarly, teeth can be related to bernissartid, goniopholid and atoposaurid crocodyliforms, but other fossils collected at the Beteta sites remain indeterminate. Nevertheless, all of the characters described are consistent with non-eusuchian Neosuchia crocodyliforms.

The preserved ankylosaur remains are similar to those of other Lower Cretaceous Spanish sites, such as Polacanthus and Europelta (Pereda-Suberbiola et al., 2007; Gasulla et al., 2011; Kirkland et al., 2013). Thus, it is preferred provisionally to refer these remains to Ankylosauria indet. The presence of ankylosaurian remains is common in other Wealden sites from Northeastern Spain (PeredaSuberbiola et al., 2007; Gasulla et al., 2011) and Southern Britain (Norman, 2011; Sweetman, 2016).

Finally, only the opisthocoelous cervical centrum from Vadillos1 is attributable to styracosternan ornithopods, previously cited in this area (Iguanodon sp.: Lapparent et al., 1969; Ruiz-Omeñaca and Canudo, 2003). The other ornithopod remains shows features that are also quite similar to that seen in a great variety of these dinosaurs, so they are best regarded as Ornithopoda indet. Ornithopod dinosaurs and more specifically styracosternan ornithopods are common forms throughout the Barremian record of Spain (Gasulla et al., 2014, 2015) and the European Wealden of Britain and Belgium (Norman, 2012), being the theropod dinosaurs notably scarcer.

\section{Conclusions}

The three new fossil sites of the Beteta Gorges described in this paper add new data to the already rich palaeontological record from the Lower Cretaceous of the Cuenca Province (Spain). Though the results presented here are still preliminary, since further sampling is intended, the diverse fossil record retrieved from the material collected in Vadillos-1, Vadillos-2 and El Tobar evidence that El Collado Formation might be as fossiliferous as La Huérguina Formation in spite of the lithological differences between the two formations. Here, at least 21 different taxa have been identified, comprising three charophytes, eight invertebrates (six ostracods, one bivalve, and one gastropod), five small vertebrates (two bony fishes, one amphibian and, at least, two crocodyliforms), and large vertebrates (at least, one turtle, one neosuchian crocodyliform and three different dinosaurs). The charophyte assemblage, marked by the presence of $A$. trivolvis triquetra, G. maillardii trochiliscoides and C. harrisii harrisii, dates the sites as upper Barremian. A partial coincidence has been observed with the taxa recorded in the wellknown nearby sites from the coeval La Huérguina Formation, such as Las Hoyas, Buenache de la Sierra or Uña, but also certain differences. The predominance of clastic sedimentation in El Collado Formation is related to an alluvial-palustrine sedimentary environment corresponding to floodplains crossed by braided sandy channels, whereas in the La Huérguina Formation 
sedimentation is predominantly lacustrine. Macroremains seemingly are scarce and found more dispersed in the new sites described here, but smaller fossils are extremely abundant, particularly in Vadillos-1. The different location of Vadillos-1, Vadillos-2 and El Tobar in the basin is most certainly responsible for the taxonomic and preservational differences observed between them. Nevertheless, the new samplings in the three sites will help to characterise with more precision these differences and will provide valuable information for a better understanding of the fossil record in the Lower Cretaceous of this region.

\section{Acknowledgements}

The authors express their gratitude to all the palaeontologists for their participation in the field-exploration and excavation campaigns at the Beteta Gorges in December 2013 and January 2014. These campaigns were carried out with authorisation 13.0113 issued by the Dirección General de Patrimonio y Museos of the Junta de Comunidades de Castilla-La Mancha, and were developed in collaboration with the Ayuntamiento de Beteta. Thanks go to to Prof. D. Santiago Prieto Villar, of the Universidad de Castilla-La Mancha (Spain), and to Prof. Dr. Steven C. Sweetman, of the University of Portsmouth (UK), and an anonymous referee for their helpful review of the original manuscript. Predoctoral Research Training Grant CT45/15-CT46/15 of the Universidad Complutense de Madrid; and Research Projects 2016/00252/001 of the Junta de Comunidades de Castilla-La Mancha, and CGL201566604, CGL2015-68363 and CGL2015-69805 of the Ministerio de Economía y Competitividad (Spain) are gratefully acknowledged.

\section{Appendix A.}

\section{Biota recorded from the new sites}

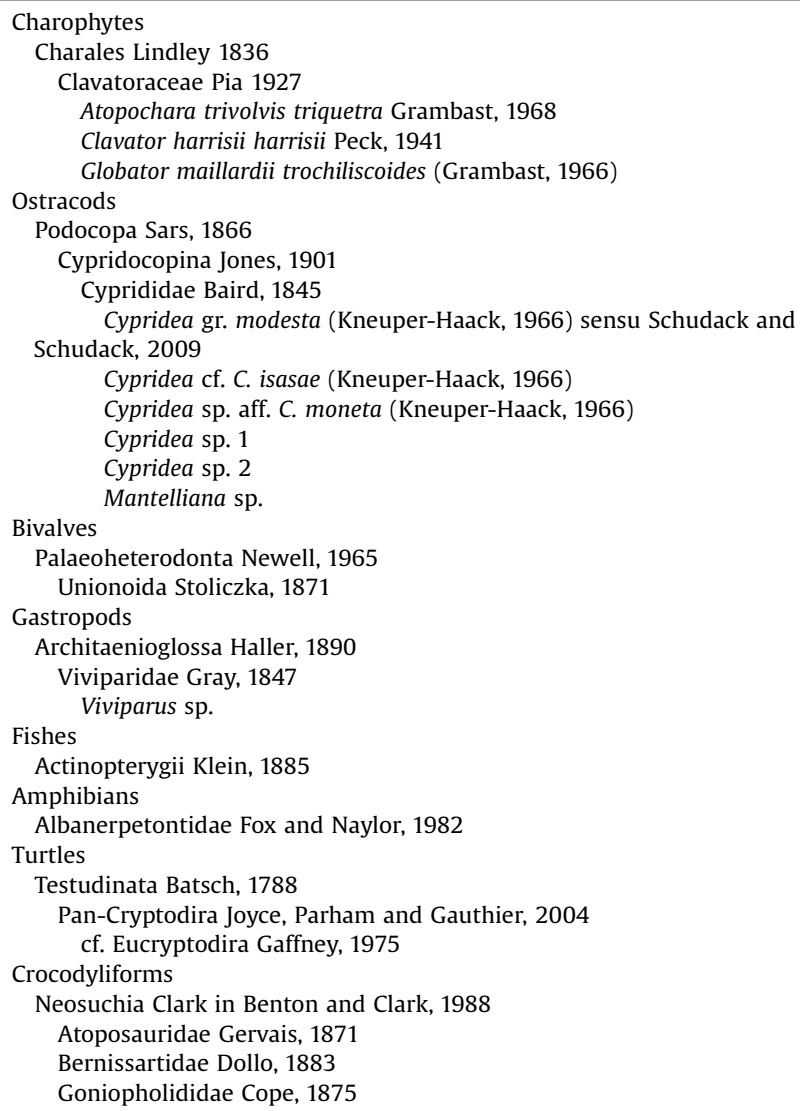

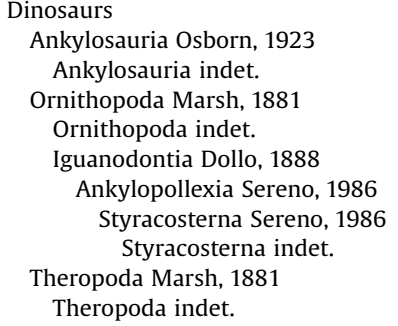

\section{References}

Aguilar, M.J., Ramírez del Pozo, J., Riba, O., 1971. Algunas precisiones sobre la sedimentación y paleoecología del Cretácico Inferior en la zona de UtrillasVillarroya de los Pinares (Teruel). Estudios Geológicos 27, 497-512.

Aguirrezabala, L.M., Torres, J.A., Viera, L.I., 1985. El Weald de Igea (Cameros-La Rioja). Sedimentología, Bioestratigrafía y Paleoecología de grandes reptiles (Dinosaurios). Munibe (Ciencias Naturales) 37, 111-138.

Alonso, A., Gasca, J.M., Navarro-Lorbés, P., Núñez-Lahuerta, C., Galán, J., Parrilla-Bel J., Rubio, C., Canudo, J.I., 2016. La asociación faunística de Barranco del Hocino 1 un nuevo yacimiento de vertebrados del Barremiense (Cretácico Inferior) de Teruel. Cuadernos del Museo Geominero 20, 303-307.

Álvaro López, M., Olmo Zamora, P.del, 1989a. Peralejos de las Truchas, 539 (9-13). Mapa Geológico de España 1:50.000. Segunda Serie. Instituto Geológico y Minero de España.

Álvaro López, M., Olmo Zamora, P.del, 1989b. Explicación de la Hoja de Peralejos de las Truchas, 539 (23-25). Mapa Geológico de España 1:50.000. Segunda Serie. IGME, Madrid 68 pp.

Barroso-Barcenilla, F., Cambra-Moo, O., Escaso, F., Ortega, F., Pascual, A., PérezGarcía, A., Rodríguez-Lázaro, J., Sanz, J.L., Segura, M., Torices, A., 2009. New and exceptional discovery in the Upper Cretaceous of the Iberian Peninsula: The palaeontological site of "Lo Hueco", Cuenca, Spain. Cretaceous Research 30, 1268-1278.

Bermúdez-Rochas, D.D., Poyato-Ariza, F., 2007. New fossiliferous sites with fish fauna from the Basque-Cantabrian and Cameros Basins, Early Cretaceous, Spain. Journal of Vertebrate Paleontology 27 (Supplement to 3), 47A-48A.

Bermúdez-Rochas, D.D., Delvene, G., Hernán, J., 2006. Estudio preliminar del contenido paleontológico del Grupo Urbión (Cretácico Inferior, Cuenca de Cameros, España): Restos ictiológicos y malacológicos. Boletín Geológico y Minero 117 561-536.

Bermúdez-Rochas, D.D., Delvene, G., Ruiz-Omeñaca, J.I., 2013. Evidence of predation in Early Cretaceous unionoid bivalves from freshwater sediments in the Cameros Basin, Spain. Lethaia 46, 57-70.

Buscalioni, A.D., Fregenal-Martínez, M.A., 2010. A holistic approach to the palaeoecology of Las Hoyas Konservat-Lagerstätte (La Huérguina Formation, Lower Cretaceous, Iberian Ranges, Spain). Journal of Iberian Geology 36, 297326.

Buscalioni, A.D., Fregenal-Martínez, M.A., Bravo, A., Poyato-Ariza, F.J., Sanchíz, B. Báez, A.M., Cambra-Moo, O., Martín-Closas, C., Evans, S.E., Marugan Lobón, J., 2008. The vertebrate assemblage of Buenache de la Sierra (Upper Barremian of Serrania de Cuenca, Spain) with insights into its taphonomy and palaecology. Cretaceous Research 29, 687-710.

Calzada Badía, S., 1977. Un yacimiento barremiense en Cameros (Logroño). Boletín de la Real Sociedad Española de Historia Natural (Geología) 75, 35-38.

Cambra-Moo, O., Barroso-Barcenilla, F, Prieto, I., Segura, M., Sevilla, P., 2014 Aproximación tafonómica a los yacimientos de vertebrados del Barremiense superior de las "Hoces de Beteta" (Cuenca, España). XXX Jornadas de la Sociedad Española de Paleontología, Libro de Resúmenes, Teruel 285-286.

Canudo, J.I., Amo, O., Cuenca-Bescós, G., Meléndez, A., Ruiz-Omeñaca, J.I., Soria, A.R 1997. Los vertebrados del Tithónico-Barremiense de Galve (Teruel, España). Cuadernos de Geología Ibérica 23, 209-241.

Canudo, J.I. Gasca, J.M., Aurell, M., Badiola, A., Blain, H.A., Cruzado-Caballero, P. Gómez-Fernández, D., Moreno-Azanza, M., Parrilla, J., Rabal-Garcés, R., RuizOmeñaca, J.I., 2010. La Cantalera: an exceptional window onto the vertebrate biodiversity of the Hauterivian-Barremian transition in the Iberian Peninsula. Journal of Iberian Geology 36, 205-224.

Capote, R., Díaz, M., Gabaldón, V., Gómez, J.J., Sánchez de la Torre, L., Ruíz, P., Ruíz, P., Rosell, J., Sopeña, A., Yébenes, Á., 1982. Evolución sedimentológica y tectónica del Ciclo Alpino en el tercio noroccidental de la Rama Castellana de la Cordillera Ibérica. IGME, Madrid 240 pp.

Curnelle, R., 1968. Études géologiques dans la Serranía de Cuenca, entre Priego et Beteta (Espagne Centrale). PhD Thesis. Université de Bordeaux, Bordeaux, pp. 175-177.

Delvene, G., Araujo, R., 2009. Protopleurobema: a new genus of freshwater bivalve from the Lower Cretaceous of the Cameros basin (NW Spain). Journal of Iberian Geology 35, 169-178.

Delvene, G., Bermúdez-Rochas, D., 2009. Freshwater association from the Cretaceous Vega del Pas Formation (Basque-Cantabrian Basin, Northern Spain). 
10th International Symposium on Mesozoic Terrestrial Ecosystems and Biota, Teruel 17-19.

Delvene, G., Munt, M., 2011. New Trigonioidoidea (Bivalvia; Unionoida) from the Early Cretaceous of Spain. Palaeontology 54, 631-638.

Delvene, G., Munt, M., Royo-Torres, R., Cobos, A., Alcalá, L., 2013. Late Jurassic-Early Cretaceous freshwater bivalves from Turiasaurus riodevensis bearing strata of Teruel (Spain). Spanish Journal of Palaeontology 28, 161-172.

Diéguez, C., Trinçao, P., Martín-Closas, C., López-Morón, N., 1995. Paleobotany. In: Meléndez, N. (Ed.), Las Hoyas: A lacustrine Konservat-Lagerstätte, Cuenca, Spain. Universidad Complutense de Madrid, Madrid, pp. 29-32.

Fallot, J., Bataller, J.R., 1927. Itinerario geológico a través del Bajo Aragón y Maestrazgo Memoria de la Real Academia Ciencias y Artes de Barcelona, 22. 143 pp.

Fernández-López, S., 2000. Temas de Tafonomía. Departamento de Paleontología. Universidad Complutense de Madrid, Madrid 167 pp.

Francés, V., Sanz, J.L., 1989. Restos de dinosaurios del Cretácico Inferior de Buenache de la Sierra (Cuenca). In: Sanz, J.L. (Ed.), La fauna del pasado en Cuenca. Instituto Juan de Valdés, Excelentísimo Ayuntamiento de Cuenca, Cuenca, pp. 125-144.

Fregenal-Martínez, M.A., 1998. Análisis de la cubeta sedimentaria de las Hoyas y su entorno paleogeográfico (Cretácico Inferior, Serranía de Cuenca).

Sedimentología y aspectos tafonómicos del Yacimiento de las Hoyas. Doctoral Thesis. Universidad Complutense de Madrid, Madrid 354 pp.

Fregenal-Martínez, M.A., Buscalioni, A., 2009. Las Hoyas Konservat-Lagerstätte: a fieldtrip to a Barremian subtropical continental wetland ecosystem. Fundamental 14, 131-147.

Fregenal-Martínez, M.A., Meléndez, N., 1993. Sedimentología y evolución paleogeográfica de la cubeta de las Hoyas (Cretácico Inferior, Serranía de Cuenca). Cuadernos de Geología Ibérica 17, 231-256.

Fregenal-Martínez, M.A., Meléndez, N., 2000. The lacustrine fossiliferous deposits of Las Hoyas Subbasin (Lower Cretaceous, Serranía de Cuenca, Iberian Ranges, Spain). In: Gierlowski-Kordesch, E.H., Kelts, K.R. (Eds.), Lake Basins Through Space and Time. AAPG, Studies in Geology 46, pp. 303-314.

Fregenal-Martínez, M.A., Meléndez, N., 2001. Unidades estratigráficas genéticas en el registro continental de la Cubeta de las Hoyas (Cretácico Inferior, Serranía de Cuenca). Geotemas 3, 185-188.

Gasulla, J.M., Ortega, F., Pereda-Suberbiola, X., Escaso, F., Sanz, J.L., 2011. Elementos de la armadura dérmica del dinosaurio anquilosaurio Polacanthus Owen, 1865, en el Cretácico Inferior de Morella (Castellón, España). Ameghiniana 48, 508 519.

Gasulla, J.M., Escaso, F., Ortega, F., Sanz, J.L., 2014. New hadrosauriform cranial remains from the Arcillas de Morella Formation (lower Aptian) of Morella, Spain. Cretaceous Research 47, 19-24.

Gasulla, J.M., Escaso, F., Narváez, I., Ortega, F., Sanz, J.L., 2015. A New Sail-Backed Styracosternan (Dinosauria: Ornithopoda) from the Early Cretaceous of Morella Spain. PL oS ONE 10, e0144167.

Gierlowski-Kordesch, E.H., Gómez-Fernández, J.C., Meléndez, N., 1991. Carbonate and coal deposition in an alluvial-lacustrine setting: Lower Cretaceous (Weald) in the Iberian Range (East-central Spain). In: Anadón, P., Cabrera, L., Kelts, K. (Eds.), Lacustrine Facies Analysis. IAS Special Publication 13, pp. 109-125.

Gómez, B., Martín-Closas, C., Meon, H., Thevenard, F., Barale, G., 2001. Plant taphonomy and palaeoecology in the lacustrine Uña Delta (late Barremian Iberian Ranges, Spain). Palaeogeography, Palaeoclimatology, Palaeoecology 170, 133-148.

Gómez-Fernández, J.C., Meléndez, N., 1991. Rhythmically laminated lacustrine carbonates in the Lower Cretaceous of La Serranía de Cuenca Basin (Iberian Ranges, Spain). In: Anadón, P., Cabrera, L., Kelts, K. (Eds.), Lacustrine Facies Analysis. IAS Special Publication 13, pp. 245-256.

Goy, A., Gómez, J.J., Yébenes, A., 1976. El Jurásico de la Rama Castellana de la Cordillera Ibérica: Mitad norte I. Unidades litoestratigráficas. Estudios Geológicos 32, 391-423.

Grambast, L., 1966. Un nouveau type structural chez les Clavatoracées, son intérêt phylogénetique et stratigrafique. Comptes Rendus des Séances de l'Académie des Sciences (Paris) 262, 1929-1932.

Grambast, L., 1968. Evolution of the utricle in the charophyta genera Perimneste Harris and Atopochara Peck. Journal of the Linnean Society (Botany) 61, 5-11.

Henkel, S., Krebs, B., 1969. Zwei Säugetier-Unterkiefer aus der Unteren Kreide von Uña (Prov. Cuenca Spanien). Neues Jahrbuch fur Geologie und Paläontologie. Monatshefte 8, 449-463.

Hooker, J., Sweetman, S., 2009. Early Cretaceous and Paleogene Vertebrate localities of the Isle of Wight, Southern England. A Field trip guide for the Society of Vertebrate Paleontology. SVP 69th Annual Meeting, Bristol, pp. 1-63.

Horne, D.J., 2002. Ostracod biostratigraphy and palaeoecology of the Purbeck Limestone Group in Southern England. Special Papers in Palaeontology 68, 53 70 .

Kirkland, J.I., Alcalá, L., Loewen, M.A., Espílez, E., Mampel, L., Wiersma, J.P., 2013. The Basal Nodosaurid Ankylosaur Europelta carbonensis n gen., n. sp. from the Lower Cretaceous (Lower Albian) Escucha Formation of Northeastern Spain. PLoS One 8, e80405.

Lapparent, A.F., de Curnelle, R., Defaut, B., Miroschedji, A., de Pallard, B., 1969. Nouveaux gisements de Dinosaures en Espagne centrale. Estudios Geológicos $25,311-315$.

López Olmedo, F., Gállego Coiduras, I.C., 1976. Nota sobre las “Facies Weald y Utrillas" del Cretácico en la Serranía del Alto Tajo. Tecniterrae 11, 17-24.

Martín-Closas, C., Clavel, B., Charollais, J., Conrad, M.A., 2009. Charophytes from the Barremian-lower Aptian of the Northern Subalpine Chains and Jura Mountains,
France: correlation with associated marine assemblages. Cretaceous Research $30,49-62$

Meléndez, F., 1971. Estudio geologico de la Serranía de Cuenca en relación a sus posibilidades petrolíferas $\mathrm{PhD}$ Thesis. Universidad Complutense de Madrid, Madrid 245 pp.

Meléndez, N., Meléndez, A., Gómez, J.C., 1989. Los sistemas lacustres del Cretácico Inferior de la Serranía de Cuenca, Cordillera Ibérica. Universidad Complutense de Madrid, Madrid 70 pp.

Norman, D.B., 2011. Ornithopod dinosaurs. In: Batten, D.J. (Ed.), Field Guide to the Wealden of England. The Palaeontological Association, Oxford, pp. 407-475.

Norman, D.B., 2012. Iguanodontian taxa (Dinosauria: Ornithischia) from the Lower Cretaceous of Britain and Belgium. In: Godefroit, P. (Ed.), Bernissart Dinosaurs and Early Cretaceous Terrestrial Ecosystems. Indiana University Press, Bloomington and Indianapolis, pp. 174-212.

Peck, R.E., 1941. Lower Cretaceous rocky mountain non marine microfossils. Journal of Paleontology 15, 285-304.

Pereda-Suberbiola, X., Fuentes, C., Meijide, M., Meijide-Fuentes, F., Meijide-Fuentes, M., 2007. New remains of the ankylosaurian dinosaur Polacanthus from the Lower Cretaceous of Soria, Spain. Cretaceous Research 28, 583-596.

Pérez-García, A., 2012. The European Lower Cretaceous Chitracephalus dumonii (Testudines: Cryptodira) and the diversity of a poorly known lineage of turtles. Acta Palaeontologica Polonica 57, 575-588.

Pérez-García, A., 2014. Revision of the poorly known Dorsetochelys typocardium, a relatively abundant pleurosternid turtle (Paracryptodira) in the Early Cretaceous of Europe. Cretaceous Research 49, 152-162.

Pérez-García, A., Murelaga, X., 2012a. Galvechelone lopezmartinezae gen. et sp. nov.: a new cryptodiran turtle in the Lower Cretaceous of Europe. Palaeontology 55, 937-944.

Pérez-García, A., Murelaga, X., 2012b. Larachelus morla gen. et sp nov., a new member of the little-known European Early Cretaceous record of stem cryptodiran turtles. Journal of Vertebrate Paleontology 32, 1293-1302.

Pérez-García, A., Murelaga, X., 2013. Camerochelys vilanovai gen. et sp. nov.: a new pan-cryptodiran turtle in the Early Cretaceous of the Iberian Range (Spain). Cretaceous Research 41, 143-149.

Pérez-García, A., Fuente, M.S. de la, Ortega, F., 2012. A new freshwater basal eucryptodiran turtle from the Early Cretaceous of Spain. Acta Palaeontologica Polonica 57, 285-298.

Pérez-García, A., Gasulla, J.M., Ortega, F., 2014. A new species of Brodiechelys (Testudines, Pan-Cryptodira) from the Early Cretaceous of Spain: systematic and palaeobiogeographic implications. Acta Palaeontologica Polonica 59, 333-342.

Pérez-García, A., Espílez, E., Mampel, L., Alcalá, L., 2015. A new European Albian turtle that extends the known stratigraphic range of the Pleurosternidae (Paracryptodira). Cretaceous Research 55, 74-83.

Peropadre, C., Meléndez, N., 2004. Las facies continentales del Cretácico Inferior en la zona meridional de la Sierra de Altomira (Cordillera Ibérica) Estratigrafía, sedimentología y discusión sobre su correlación regional. Revista de la Sociedad Geológica de España 17, 117-135.

Poyato-Ariza, F.J., Talbot, M.R., Fregenal-Martínez, M.A., Meléndez, N., Wenz, S., 1998. First isotopic and multidisciplinary evidence for nonmarine coelacanths and pycnodontiform fishes: paleoenvironmental implications. Palaeogeography, Palaeoclimatology, Palaeoecology 144, 65-84.

Prieto, I., Barroso-Barcenilla, F., Segura, M., Ruiz-Galván, A., 2013a. Contexto geológico de los nuevos yacimientos Barremienses de vertebrados en las "Hoces de Beteta" (Cuenca, España). In: Navas-Parejo, P., Martínez-Pérez, C., Pla-Pueyo, S. (Eds.), Trending Topics in Paleontology. Atarfe, Granada, pp. 89-91.

Prieto, I., Segura, M., Sevilla, P., 2013b. Geology and stratigraphy of the new Barremian vertebrate sites in the Beteta Gorges (Cuenca, Spain). In: GarcíaHidalgo, J.F., Gil Gil, J., Barroso-Barcenilla, F., López Olmedo, F., Díaz de Neira, J.A. (Eds.), V Congreso del Cretácico de España. IGME, Madrid, pp. 72.

Prieto, I., Barroso-Barcenilla, F., Segura, M., 2014. Aproximación paleoambiental a los yacimientos de vertebrados del Barremiense superior de las "Hoces de Beteta" (Cuenca, España). In: Arreguín-Rodríguez, G., Colmenar, J., Díaz-Berenguer, E., Galán, J., Legarda-Lisarri, A., Parrilla-Bel, J., Puértolas-Pascual, E., Silva-Casal, R. (Eds.), New Insights on Ancient Life. Boltaña, Huesca, pp. 98-100.

Prieto, S., Díaz-Romeral, A., 1989. El yacimiento de Las Hoyas: historia de un descubrimiento. In: Sanz, J.L. (Ed.), La fauna del pasado en Cuenca. Instituto Juan de Valdés, Excelentísimo Ayuntamiento de Cuenca, Cuenca, pp. 39-50.

Puértolas-Pascual, E., Rabal-Garcés, R., Canudo, J.I., 2015. Exceptional crocodylomorph biodiversity of "La Cantalera" site (Lower Barremian, Lower Cretaceous) in Teruel, Spain. Paleontologia Electronica 18.2.28A, 1-16.

Ramírez, J., Meléndez, F., 1972. Nuevos datos sobre el Cretácico Inferior en facies Weald de la Serranía de Cuenca. Boletín Geológico y Minero 83, 569-581.

Robles-Cuenca, F., 1986. Gasterópodos. In: López-Martínez, N. (Ed.), Guía de campo de los fósiles de España. Pirámide, Madrid, pp. 182-230.

Ruiz-Galván, A., Barroso-Barcenilla, F., Sanz, J.L., 2013a. Fossil content of the new vertebrate sites in the Lower Cretaceous of the Beteta Gorges (Cuenca, Spain). In: García-Hidalgo, J.F., Gil Gil, J., Barroso-Barcenilla, F., López Olmedo, F., Díaz de Neira, J.A. (Eds.), V Congreso del Cretácico de España. IGME, Madrid, pp. 74.

Ruiz-Galván, A., Sanz, J.L., Sevilla, P., Prieto, I., 2013b. Nuevos yacimientos de vertebrados en el Cretácico Inferior de las “Hoces de Beteta” (Cuenca, España). In: Navas-Parejo, P., Martínez-Pérez, C., Pla-Pueyo, S. (Eds.), Trending Topics in Paleontology. Atarfe, Granada, pp. 98-100.

Ruiz-Galván, A., Sanz, J.L., Sevilla, P., 2014. Microfósiles de los yacimientos barremienses de las "Hoces de Beteta" (Cuenca, España). Primeros resultados. In: Arreguín-Rodríguez, G., Colmenar, J., Díaz-Berenguer, E., Galán, J., Legarda- 
Lisarri, A., Parrilla-Bel, J., Puértolas-Pascual, E., Silva-Casal, R. (Eds.), New Insights on Ancient Life, , pp. 109-112 Boltaña Huesca.

Ruiz-Omeñaca, J.I., 2006. Restos directos de dinosaurios (Saurischia, Ornithischia) en el Barremiense (Cretácico Inferior) de la Cordillera Ibérica en Aragón (Teruel, España). PhD Thesis. Universidad de Zaragoza, Zaragoza 439 pp.

Ruiz-Omeñaca, J.I., Canudo, J.I., 2003. Dinosaurios (Saurischia Ornitischia) en el Barremiense (Cretácico Inferior) de la Península Ibérica. dinosaurios y otros reptiles Mesozoicos en España. Ciencias de la Tierra 26, , pp. 269-312.

Ruiz-Omeñaca, J.I., Canudo, J.I., Cuenca-Bescós, G., 1997. Primera evidencia de un área de alimentación de dinosaurios herbívoros en el Cretácico Inferior de España (Teruel). Monografías de la Academia de Ciencias Exactas, Físicas, Químicas y Naturales de Zaragoza 10, 1-48.

Ruiz-Omeñaca, J.I., Canudo, J.I., Cuenca Bescós, G., 1998. Sobre las especies de Iguanodon (Dinosauria, Ornithischia) encontradas en el Cretácico inferior de España. Geogaceta 24, 275-277.

Ruiz-Omeñaca, J.I., Canudo, J.I., Aurell, M., Badenas, B., Cuenca-Bescós, G., Ipas, J., 2004. Estado de las investigaciones sobre los vertebrados del Jurásico Superior y el Cretácico Inferior de Galve (Teruel). Estudios Geológicos 60, 179-202.

Salas, R., Guimerà, J., Mas, R., Martín-Closas, C., Meléndez, A., Alonso, A., 2001. Evolution of the Mesozoic Central Iberian Rift System and its Cainozoic inversion (Iberian chain). In: Ziegler, P.A., Cavazza, W., Robertson, A.H.F. Crasquin-Soleau, S. (Eds.), Peri-Tethys Memoir 6. Mémoires du Muséum National d'Histoire Naturelle, 186. 145-185.

Sanz, J.L., 1985. Nouveaux gisements de dinosaures dans le Crétacé espagnol. Les Dinosaures de la Chine à la France. Museum d'Histoire Naturelle de Toulouse, , pp. 81-88.

Sanz, J.L., Wenz, S., Yébenes, A., Estes, R., Martínez-Delclòs, X., Jiménez-Fuentes, E., Diéguez, C., Buscalioni, A.D., Barbadillo, L.J., Vía, L., 1988. An Early Cretaceous faunal and floral continental assemblage: Las Hoyas fossil site (Cuenca, Spain). Geobios 21, 611-635.

Sanz, J.L., Diéguez, C., Fregenal-Martínez, M.A., Martínez Delclós, X., Meléndez, N., Poyato-Ariza, F.J., 1990. El yacimiento de fósiles del Cretácico inferior de Las Hoyas, Provincia de Cuenca (España), in Comunicaciones de la Reunión de Tafonomía y Fosilización. Universidad Complutense de Madrid-CSIC, Madrid, pp. 337-355.

Scheyer, T.M., 2007. Comparative bone histology of the turtle shell (carapace and plastron): implications for turtle systematics, functional morphology, and turtle origins Doctoral Thesis. Universität Bonn, Bonn 343 pp.

Schopf, J.M., 1975. Modes of fossil preservation. Review of Paleobotany and Palynology 20, 27-53.
Schudack, U., Schudack, M., 2009. Ostracod biostratigraphy in the Lower Cretaceous of the Iberian chain (eastern Spain). Journal of Iberian Geology 35, 141-168.

Sweetman, S.C., 2006. The tetrapod microbiota of the Wessex Formation (Lower Cretaceous, Barremian) of the Isle of Wight, UK. 127-129. In: Barrett, P.M., Evans, S.E. (Eds.), 9th International Symposium on Mesozoic Terrestrial Ecosystems and Biota, Abstracts and Proceedings, London, pp. 1-7.

Sweetman, S.C., 2016. A comparison of Barremian-early Aptian vertebrate assemblages from the Jehol Group, noth-east China and the Wealden Group, southern Britain: the value of microvertebrate studies in adverse preservational settings. Palaeobiodiversity and Palaeoenvironments 96, 149-167.

Sweetman, S.C. Insole, A.N 2010. The plant debris beds of the Early Cretaceous (Barremian) Wessex Formation of the Isle of Wight, southern England: their genesis and paleontological significance. Palaeogeography, Palaeoclimatology, Palaeoecology 292, 409-424.

Sweetman, S.C., Goederet, J., Martill, D.M., 2014. A preliminary account of the fishes of the Lower Cretaceous Wessex Formation (Wealden Group, Barremian) of the Isle of Wight, southern England. Biological Journal of the Linnean Society 113, 872-896.

Viallard, P., 1966. Sur le Crétacé de la Chaine Ibérique castillane entre le Río Turia et la haute-vallée du Río Júcar ( province de Valencia et Cuenca, Espagne). Comptes Rendus de l'Académie des Sciences 262, 1997-2000.

Viallard, P., 1968. Le Crétacé inférieur dans la zone marginale sud-occidentale de la Chaine Ibérique. Compte Rendu Sommaire de la Société Géologique de France 9, 321-323.

Vicente, A., Martín-Closas, C., 2013. Lower Cretaceous charophytes from the Serranía de Cuenca, Iberian Chain: taxonomy, biostratigraphy and palaeoecology. Cretaceous Research 40, 227-242.

Viera, L.I., Torres, J.A., 1996. Nuevos datos paleontológicos en el área de Hornillos de Cameros. Estrato 7, 114-118.

Vilas, L., Mas, R., García, A., Arias, C., Alonso, A., Meléndez, N., Rincón, R., 1982. Ibérica Suroccidental. In: García, A. (Ed.), El Cretácico de España. Universidad Complutense de Madrid, Madrid, pp. 457-513.

Wright, V.P., 1999. Assessing flood duration gradients and fine-scale environmental change on ancient floodplains. In: Marriot, S.B., Alexander, J. (Eds.), Floodplains; interdisciplinary approaches, 163. Geological Society Special Publications, pp. 279-287.

Wright, V.P., Taylor, K.G., Beck, V.H., 2000. The paleohidrology of Lower Cretaceous seasonal wetlands, Isle of Wight, Southern England. Journal of Sedimentary Research 70, 619-632. 